\title{
Amyloid beta protein-induced zinc sequestration leads to synaptic loss via dysregulation of the ProSAP2/Shank3 scaffold
}

\author{
Andreas M Grabrucker ${ }^{1,2 \dagger}$, Michael J Schmeisser ${ }^{1 \dagger}$, Patrick T Udvardi ${ }^{1}$, Magali Arons ${ }^{2}$, Michael Schoen ${ }^{1}$, \\ Nathaniel S Woodling ${ }^{3}$, Katrin I Andreasson ${ }^{3}$, Patrick R Hof ${ }^{4,5}$, Joseph D Buxbaum ${ }^{4,5,6,7}$, Craig C Garner ${ }^{2}$ and \\ Tobias M Boeckers ${ }^{1 *}$
}

\begin{abstract}
Background: Memory deficits in Alzheimer's disease (AD) manifest together with the loss of synapses caused by the disruption of the postsynaptic density (PSD), a network of scaffold proteins located in dendritic spines. However, the underlying molecular mechanisms remain elusive. Since it was shown that ProSAP2/Shank3 scaffold assembly within the PSD is $\mathrm{Zn}^{2+}$-dependent and that the amyloid beta protein $(\mathrm{A} \beta)$ is able to bind $\mathrm{Zn}^{2+}$, we hypothesize that sequestration of $\mathrm{Zn}^{2+}$ ions by $\mathrm{A} \beta$ contributes to ProSAP/Shank platform malformation.

Results: To test this hypothesis, we designed multiple in vitro and in vivo assays demonstrating ProSAP/Shank dysregulation in rat hippocampal cultures following $A \beta$ oligomer accumulation. These changes were independent from alterations on ProSAP/Shank transcriptional level. However, application of soluble A $\beta$ prevented association of $\mathrm{Zn}^{2+}$ ions with ProSAP2/Shank3 in a cell-based assay and decreased the concentration of $\mathrm{Zn}^{2+}$ clusters within dendrites. $\mathrm{Zn}^{2+}$ supplementation or saturation of $\mathrm{A} \beta$ with $\mathrm{Zn}^{2+}$ ions prior to cell treatment was able to counter the effects induced by A $\beta$ on synapse density and ProSAP2/Shank3 levels at the PSD. Interestingly, intracellular $\mathrm{Zn}^{2+}$ levels in APP-PS1 mice and human AD hippocampus are reduced along with a reduction in synapse density and synaptic ProSAP2/Shank3 and Shank1 protein levels.

Conclusions: We conclude that sequestration of $\mathrm{Zn}^{2+}$ ions by A $\beta$ significantly contributes to changes in ProSAP2/ Shank3 platforms. These changes in turn lead to less consolidated (mature) synapses reflected by a decrease in Shank1 protein levels at the PSD and decreased synapse density in hippocampal neurons.
\end{abstract}

Keywords: PSD, Alzheimer?'?s disease, ProSAP2, Shank3, Shank1, Amyloid, Oligomers, $\mathrm{Zn}^{2+}$, Hippocampus, synapse

\section{Background}

The loss of synapses is closely associated with the cognitive impairment seen in patients with Alzheimer's disease (AD) [1-3]. Recent findings suggest that this loss is mediated by increasing levels of amyloid beta protein $(A \beta)$, a product of amyloid precursor protein (APP) metabolism [4-6], although the mechanisms through which $A \beta$ accumulation finally leads to synaptic degeneration are not fully understood. However, Pham et al.

\footnotetext{
* Correspondence: tobias.boeckers@uni-ulm.de

+ Contributed equally

'Institute for Anatomy and Cell Biology, Ulm University, Albert Einstein Allee 11, Ulm, 89081, Germany

Full list of author information is available at the end of the article
}

have recently shown that $A \beta$ oligomers progressively accumulate in brains of AD patients as well as in APP transgenic mice together with a reduction in the levels of synaptic scaffold proteins such as Shank1 and ProSAP2/Shank3 [7].

Proteins of the ProSAP/Shank (Synamon, CortBP, Spank, SSTRIP) family play a crucial role in proper synapse function [8] and have been linked to autism, schizophrenia and AD [7-13]. Treatment of rat frontocortical neurons with soluble $A \beta_{1-40}$ resulted in a significant thinning of the PSD and in decreased synaptic levels of Shank1 [13] and other ProSAP/Shank platformassociated PSD proteins such as PSD-95 [14], Homer [13] and GKAP/SAPAP [15]. Although the precise 
mechanism of ProSAP/Shank scaffold protein dysregulation still remains unclear, an emerging model is that alterations in those proteins could interfere with cognitive function and behavior by impairing excitatory glutamatergic synapses.

ProSAP/Shank platforms are organized through $\mathrm{Zn}^{2}$ ${ }^{+}$-ions [16-18] and ProSAP/Shank protein levels depend on the local $\mathrm{Zn}^{2+}$ concentration and influx [17]. $\mathrm{Zn}^{2+}$ is found in PSDs and in synaptic vesicles at glutamatergic synapses throughout the neocortex and hippocampus and is released during synaptic activity [19]. Intriguingly, high concentrations of $\mathrm{Zn}^{2+}$ are also observed in neuritic plaques and cerebrovascular amyloid deposits from both $\mathrm{AD}$ patients and $\mathrm{AD}$-prone transgenic mice [20-22]. $A \beta$ is a metal-binding protein with high affinity for copper and zinc $[23,24]$ and $\mathrm{Zn}^{2+}$ ions promote $\mathrm{A} \beta$ oligomerization [25].

In our study, we show that soluble oligomers of $A \beta_{1-40}$ and $A \beta_{1-42}$ induce changes in ProSAP/Shank protein levels at the synapse. These changes are not caused by a reduced ProSAP/Shank gene expression, but reflect an altered localization of ProSAP/Shank family members. $A \beta$ seems to efficiently compete with $\mathrm{Zn}^{2+}$ loading of ProSAP2/Shank3 finally leading to a decrease in dendritic $\mathrm{Zn}^{2+}$ signals. The decline in synapse density and ProSAP2/Shank3 levels can be rescued by supplementation with $\mathrm{Zn}^{2+}$-ions or saturation of $\mathrm{A} \beta$ with $\mathrm{Zn}^{2+}$. Furthermore, in APP-PS1 mice and human $\mathrm{AD}$ brain sections, $\mathrm{Zn}^{2+}$ sequestration in senile plaques is accompanied by a decrease in intracellular $\mathrm{Zn}^{2+}$ concentration along with a decrease in synapse density and synaptic ProSAP2/Shank3 and Shank1 protein levels.

Thus, our results lead to a model illustrating that $A \beta$ pathology is at least in part caused by trapping synaptic $\mathrm{Zn}^{2+}$ in $\mathrm{A} \beta$ complexes, preventing $\mathrm{Zn}^{2+}$ from reaching its postsynaptic targets like ProSAP/Shank proteins, ultimately leading to a dysregulation of the postsynaptic scaffold and subsequent loss of synapses which might in turn lead to the observed cognitive deficits in AD.

\section{Results}

Soluble $A \beta$ oligomers induce changes in synapse density, maturation state and synaptic ProSAP2/Shank3 and Shank1 protein levels in primary hippocampal neurons

Based on recent data showing that $A \beta$ induces the disruption of the Homer1b and Shank1 scaffold [13], we investigated if soluble $A \beta$ oligomers are sufficient to induce changes in ProSAP/Shank family members. We applied 1 $\mu \mathrm{MA} \beta_{1-40}$ or $\mathrm{A} \beta_{1-42}$ to rat primary hippocampal cell culture neurons (DIV15-17) and fixed them after 1, 3, 6 and $24 \mathrm{~h}$, respectively. Immunohistochemistry was performed using anti-ProSAP2/Shank3 and anti-Shank1 antibodies co-stained with an anti-Bassoon antibody as a presynaptic marker. Synapse density was calculated by measuring the number of synapses (Bassoon and ProSAP/Shank positive sites) per unit dendrite length. The mean synapse density was significantly decreased after 6-24 h exposure to $A \beta_{1}$. ${ }_{40}$, leading to a $30 \%$ reduction in synapse density after $24 \mathrm{~h}$ (Figure $1 \mathrm{~A}$ and $\mathrm{A} \beta_{1-42}$, Additional file $1 \mathrm{~A}$ ).

To assess the maturation state of synapses, we characterized the morphology of dendritic spines in $A \beta$-treated cultures (Figure 1B). The results show that the proportion of "filopodia like" and "thin" spines, representing immature synapses with respect to the total synapse number, increased after $24 \mathrm{~h} \mathrm{~A} \beta$ treatment compared to control conditions (Figure 1B). This shift towards immature spines was accompanied by a decrease of mature ("mushroom and stubby") spines.

ProSAP/Shank family members are recruited to synapses in a sequential and development-dependent manner [17] beginning with ProSAP1/Shank2 that becomes concentrated at the sites where PSDs are thought to form [26], followed by ProSAP2/Shank3 protein. Finally, with sufficient amount of ProSAP1/Shank2 and ProSAP2/Shank3 present at the synapse, the clustering of Shank1 leads to maturation of the synaptic contacts and to spines with a mushroom-like appearance [27]. Hence, a shift towards immature spines should also influence the levels of Shank1 at synapses and we therefore measured the mean grey value and mean area of ProSAP2/Shank3 and Shank1 signals opposite to Bassoon signals (Figure 1C). In hippocampal neurons, ProSAP2/ Shank3 and Shank1 proteins were significantly downregulated at the synapse after $24 \mathrm{~h}$ treatment with $A \beta_{1-40}$ $\left(18 \% \pm 2 \%\right.$ and $30 \pm 7 \%$, respectively; $A \beta_{1-42}$, Additional file 1B) along with a downregulation of Homer 1 and PSD-95 (Additional file 1C). The protein levels of Bassoon were not significantly affected (Figure 1C). A similar decrease was observed in cortical neurons, however here, a downregulation occurred as early as $1 \mathrm{~h}$ after treatment as reported previously [13] (Additional file 1D). The observed changes were caused by a decrease of protein levels at the synapse since the mean signal area was unaffected after $A \beta$ treatment (Additional file $1 \mathrm{E}$ ). Cumulative histograms illustrate that the puncta intensity values are shifted across the entire populations of ProSAP2/ Shank3 and Shank1 puncta, revealing that mature synapses were affected by the treatment similarly to immature synapses (Additional file $1 F$ ). We thus conclude that exposure of neurons to $A \beta$ causes the loss of synapses and that decreased ProSAP2/Shank3 and Shank1 levels following $A \beta$ application, lead to altered maturation states of excitatory synapses.

\section{$A \beta_{1-40}$ oligomer-induced changes in ProSAP/Shank protein levels are not mediated via transcriptional regulation}

The changes in synaptic ProSAP/Shank levels after exposure to $A \beta_{1-40}(1 \mu \mathrm{M})$ in vitro could further be 
A
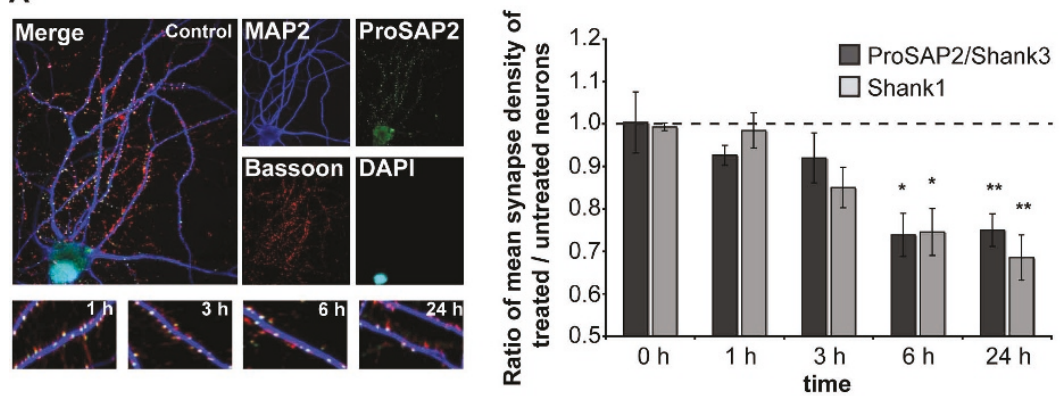

B
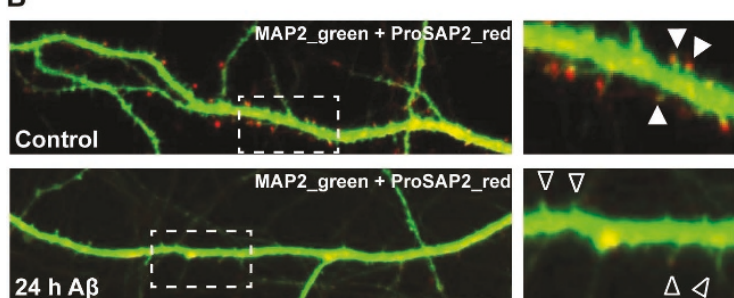

$\nabla \nabla$
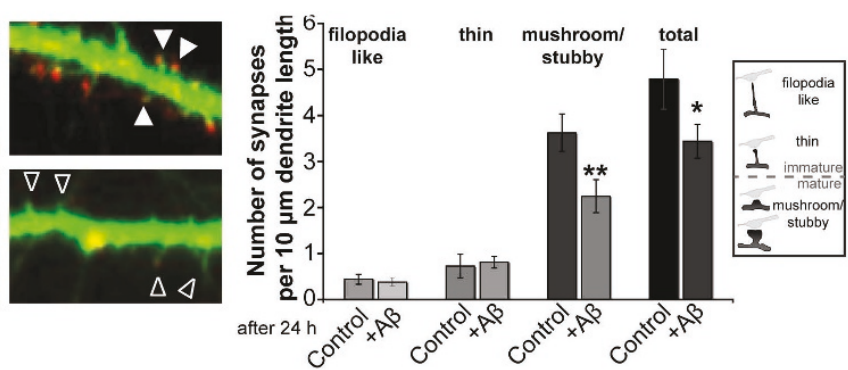

\section{C}
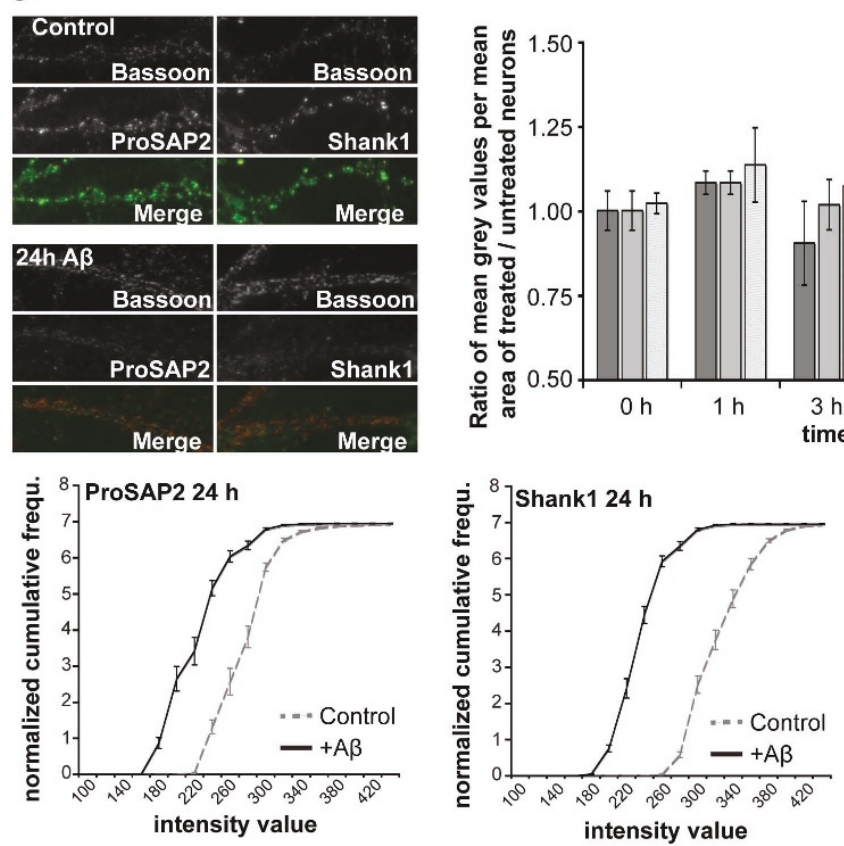

Figure 1 Soluble $A \beta$ oligomers reduce synapse density and dysregulate ProSAP/Shank family members in hippocampal cell culture. A) Changes in synapse density along the dendrites of hippocampal neurons, cultured for 15 DIV, treated with $1 \mu \mathrm{M} A \beta_{1-40}$ and fixed after $0,1,3,6$, and 24 h. Synapses along MAP2 positive dendrites were identified with antibodies against Bassoon as presynaptic marker and ProSAP2/Shank3 (left panel) or Shank1. Synapse density was calculated measuring the number of synapses per unit dendrite length of ten cells of three independent experiments for every time-point and condition (right panel). B) Spine maturation state after $24 \mathrm{~h} \mathrm{~A} \beta_{1-40}$ treatment was assessed by quantifying spine morphology (using ProSAP2/Shank3 immunoreactivity) along MAP2 positive dendrites (left panels). Spines were classified as "filopodia like", "thin" (immature) and "mushroom and stubby" (mature). The overall fraction of filopodia like and thin synapses is higher after $24 \mathrm{~h} \mathrm{A \beta}$ treatment compared to control conditions (24 h treatment with DMSO). C) A 3 treatment causes a progressive synaptic loss of ProSAP2/Shank3 and Shank1. Cultured hippocampal neurons were immunostained with antibodies against Bassoon and ProSAP2/Shank3 or Shank1 (upper left panel) and the ratio of mean grey values per mean signal area between treated and untreated neurons were measured after 1, 3, 6 or $24 \mathrm{~h}$ treatment with $A \beta_{1-40}$ (upper right panel). Cumulative histograms illustrate that the puncta intensity values are shifted across the entire populations of ProSAP2/Shank3 and Shank1 puncta (bottom panels). Data derive from 3 independent experiments at each time-point and condition representing approx. 2,500 signals per experiment. 
confirmed by Western Blotting of P2 membrane fractions from hippocampal neurons at 15 DIV after $A \beta-$ treatment for 6 and $24 \mathrm{~h}$. Compared to untreated cells (time-point 0), significantly lower levels of ProSAP2/ Shank3 (6 and $24 \mathrm{~h}$ ) and Shank1 (24 h) within the P2 fraction of lysates could be detected after 24 h of $A \beta_{1-}$ 40 treatment - similar to the effect observed by grey value measurement of immunohistochemical ProSAP2/ Shank3 and Shank1 signals at the synapse (Figure 2A, for comparison see Figure 1C). After $24 \mathrm{~h}$ of treatment, Homer1 also showed a significant decrease in protein levels and PSD-95 a clear trend towards downregulation (Figure 2A, $\beta$-III Tubulin was used as control).
To assess if the observed changes in ProSAP/Shank protein levels at synapses were due to changes in gene expression levels, we performed quantitative RT-PCR (Figure 2B). Hippocampal neurons (DIV15) were treated with $A \beta_{1-40}$ and mRNA was extracted after 1, 6, and 24 $h$. The results showed no significant differences in gene expression levels compared to controls indicating that the observed changes are due to a structural alteration of the PSD scaffold leading to a shift of ProSAP2/ Shank3 from a PSD bound state to a soluble pool. Indeed, the ratio between ProSAP2/Shank3 within the S2 soluble (Additional file 2A) and P2 membrane (Figure $2 \mathrm{~A}$ ) fraction set to 1 at time-point 0 rises to 1.59 at $6 \mathrm{~h}$ and 1.69 at $24 \mathrm{~h}$ after treatment with $\mathrm{A} \beta$. This is

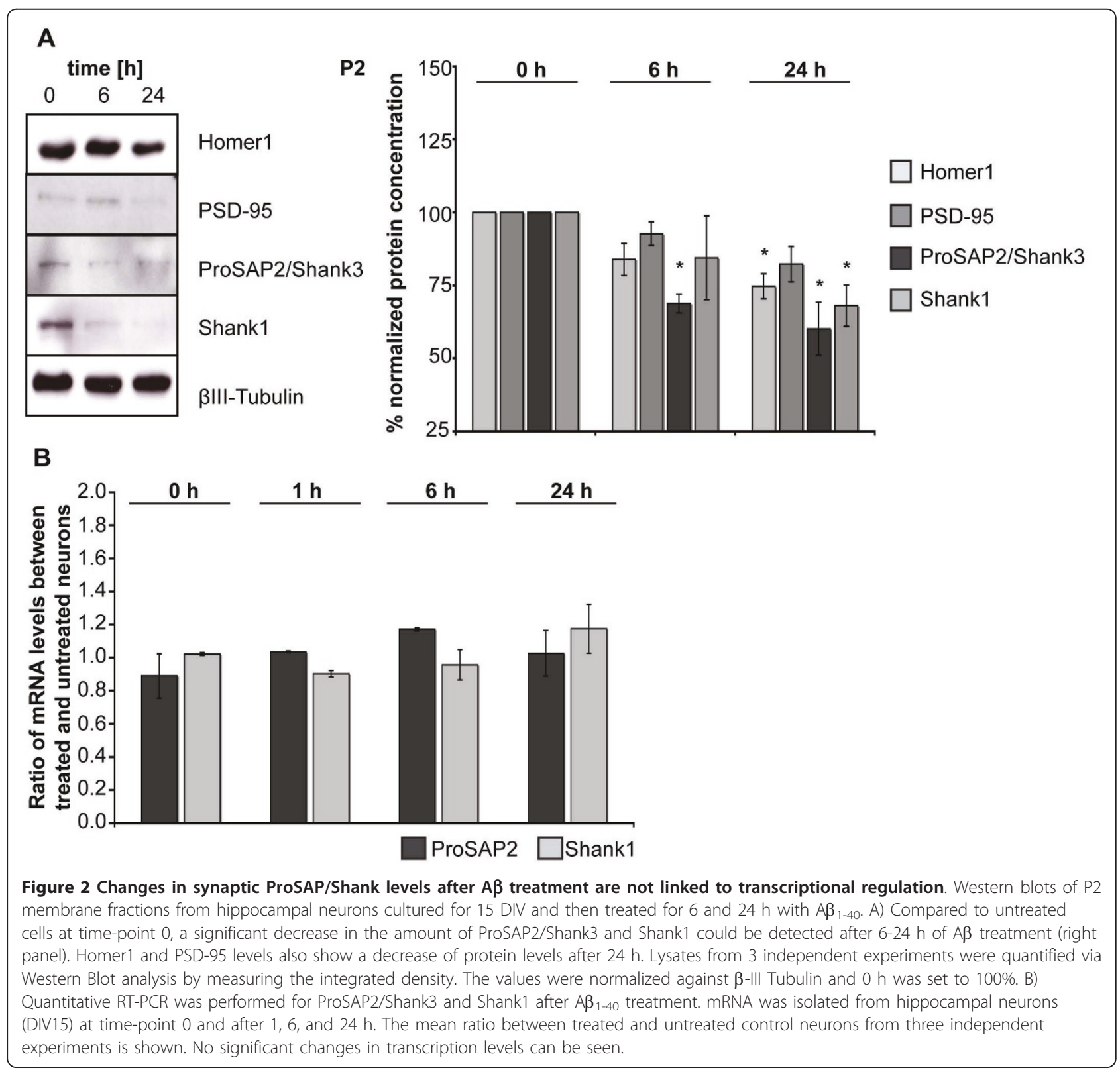


underlined by data showing that the reduction of ProSAP2/Shank3 and Shank1 at the synapse is independent of both, proteasomal degradation and protein synthesis, since treatment with the proteasome inhibitor MG132 or protein synthesis inhibitor cycloheximide (CHX) did not prevent $A \beta_{1-40}$-induced changes in synaptic signal intensities of ProSAP2/Shank3 and Shank1. However, MK801, an NMDAR antagonist, significantly decreased the amount of $A \beta_{1-40}$-induced changes in Shank1 levels as shown before [13] (Additional file 2B).

Zinc sequestration by $A \beta$ influences ProSAP2/Shank3 $\mathrm{Zn}^{2+}$ loading and leads to lower intracellular $\mathrm{Zn}^{2+}$ levels in hippocampal neurons

Since ProSAP2/Shank3 protein levels at the PSD are sensitive to the local $\mathrm{Zn}^{2+}$ concentration [17] and $\mathrm{A} \beta$ has a $\mathrm{Zn}^{2+}$-binding site and might thus be able to sequester $\mathrm{Zn}^{2+}$ ions, we investigated if $\mathrm{A} \beta$ is indeed able to sequester extracellular $\mathrm{Zn}^{2+}$ ions affecting the $\mathrm{Zn}^{2+}$ loading of ProSAP2/Shank3. To that end, we transfected

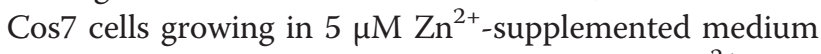
with GFP-ProSAP2/Shank3 and depleted $\mathrm{Zn}^{2+}$-ions using TPEN (Figure 3A). After $\mathrm{Zn}^{2+}$ depletion, $\mathrm{Zn}^{2+}$ ions were introduced back into the medium via $\mathrm{ZnCl}_{2}$ with and without additional $\mathrm{A} \beta$ treatment. Furthermore, as a control, $\mathrm{A} \beta$ was preloaded with $\mathrm{Zn}^{2+}$ ions and then added to the medium followed by $\mathrm{ZnCl}_{2}$ application. For these experiments, we took advantage of a dye (Zinquin) that fluoresces when it binds $\mathrm{Zn}^{2+}$ [28] to measure the local $\mathrm{Zn}^{2+}$ concentration (correlating with Zinquin signal intensity) colocalizing with GFP-ProSAP2/Shank3 clusters. The results show that in control cells, GFPProSAP2/Shank3 colocalizes with $\mathrm{Zn}^{2+}$ (Figure 3A, $\mathrm{t}=0$ min, B). After $10 \mathrm{~min}$ application of the $\mathrm{Zn}^{2+}$ chelator TPEN, $\mathrm{Zn}^{2+}$-ions were efficiently removed from ProSAP2/Shank3 clusters (Figure 3A, $t=10 \mathrm{~min}, \mathrm{~B}, \mathrm{C}$ ). Supplementation with $10 \mu \mathrm{M} \mathrm{ZnCl}_{2}$ restored and increased the initial $\mathrm{Zn}^{2+}$ association of ProSAP2/Shank3 (Figure $3 \mathrm{~A}$ left panel $\mathrm{t}=50 \mathrm{~min}, \mathrm{~B}, \mathrm{C})$. However, $20 \mathrm{~min}$ application of $10 \mu \mathrm{MA} \beta_{1-40}$ (red fluorescence) followed by supplementation of the medium with $10 \mu \mathrm{M} \mathrm{ZnCl}_{2}$ for 20 min only resulted in a minor increase in $\mathrm{Zn}^{2+}$ loading of ProSAP2/Shank3 (Figure 3A, middle panel $t=50$ min, $\mathrm{B}, \mathrm{C}$ ). In contrast, preloading of $10 \mu \mathrm{M} \mathrm{A} \beta_{1-40}$ (red fluorescence) with $10 \mu \mathrm{M} \mathrm{ZnCl}$ followed by supplementation of the medium with $10 \mu \mathrm{M} \mathrm{ZnCl}$, led to a significantly higher increase in ProSAP2/Shank3 $\mathrm{Zn}^{2+}$ loading (Figure $3 \mathrm{~A}$, right panel, $\mathrm{t}=50 \mathrm{~min}, \mathrm{~B}, \mathrm{C}$ ). Thus, $\mathrm{A} \beta$ influences $\mathrm{Zn}^{2+}$ loading of ProSAP2/Shank3 by sequestering extracellular $\mathrm{Zn}^{2+}$-ions. Because $\mathrm{Zn}^{2+}$-ions pass through the extracellular space into the postsynaptic compartment after activity-dependent vesicle release, it could well be that $A \beta$ oligomers accumulating in the synaptic cleft interfere with this process.
As the observed changes in synapse density and synaptic levels of ProSAP/Shank within 6-24 h after treatment with $A \beta$ are relatively fast, we followed the possibility that intracellular $A \beta$ contributes to a dysregulation of intracellular $\mathrm{Zn}^{2+}$ levels in neurons. Indeed, application of fluorescently-tagged $A \beta$ to hippocampal neurons in cell culture was followed by intracellular colocalization of $\mathrm{A} \beta$ and $\mathrm{Zn}^{2+}$ (Figure $4 \mathrm{~A}$, arrows). Since these neurons were cultivated in medium without $\mathrm{Zn}^{2}$ ${ }^{+}$-supplementation, $\mathrm{Zn}^{2+}$ ions colocalizing with $\mathrm{A} \beta$ are most likely depleting other $\mathrm{Zn}^{2+}$ stores. We therefore investigated postsynaptic $\mathrm{Zn}^{2+}$ levels of hippocampal neurons after treatment with $A \beta$ Zinquin labels postsynaptic $\mathrm{Zn}^{2+}$ (Additional file 3A), which is in line with previous studies that revealed a striking colocalization of dendritic ProSAP2/Shank3 and Zinquin, colocalizing apposed to presynaptic boutons loaded with the styryl dye FM [17]. A significant reduction of $\mathrm{Zn}^{2+}$ signals within dendrites (Figure 4B and Additional file 3B) was seen after $A \beta$ treatment.

\section{$\mathrm{Zn}^{2+}$ supplementation leads to a rescue of $A \beta$ induced decrease in synapse density and ProSAP2/Shank3 levels at the synapse}

Based on the results obtained through the previous experiments, we investigated if $\mathrm{Zn}^{2+}$ supplementation along with $A \beta_{1-40}$ treatment or the saturation of $A \beta_{1-40}$ with $\mathrm{Zn}^{2+}$ before treatment led to a rescue of the observed changes in synapse density and ProSAP2/ Shank3 protein levels at the PSD. Therefore, hippocampal neurons (DIV15) were treated with $A \beta_{1-40}$ and supplemented with equimolar levels of $\mathrm{ZnCl}_{2}$ or with equimolar $\mathrm{ZnCl}_{2}$ preincubated with $\mathrm{A} \beta_{1-40}$ (Figure 5). Synapse density and protein levels of ProSAP2/Shank3 at the synapse were measured as described above (Figure 1). The results show that after treatment for 1,6 and $24 \mathrm{~h}$, neither control (DMSO-supplemented) nor 1

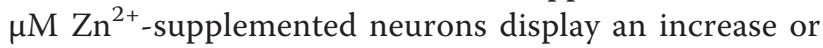
decrease in synapse density (Figure 5A, B). However, treatment with $1 \mu \mathrm{M} \mathrm{A} \beta_{1-40}$ resulted in a significant decrease of synapse density after 6 and 24 h (Figure $5 \mathrm{~A})$. In contrast, treatment of hippocampal neurons with $1 \mu \mathrm{MA} \beta_{1-40}$ preincubated for $1 \mathrm{~h}$ on ice with 1 $\mu \mathrm{M} \mathrm{ZnCl}{ }_{2}$ led to a significantly higher synapse density compared to treatment with $1 \mu \mathrm{M} \mathrm{A} \beta_{1-40}$ after 6 and 24 h. Saturation of $A \beta$ with $\mathrm{Zn}^{2+}$ thus ameliorates the effects of $A \beta$ on synapse density. To investigate, if supplementation of $\mathrm{Zn}^{2+}$ after $\mathrm{A} \beta$-induced decrease in synapse density can rescue the effects of $A \beta$ we treated hippocampal neurons (DIV15) for $18 \mathrm{~h}$ with $1 \mu \mathrm{M}$ or 10 $\mu \mathrm{M} \mathrm{A} \beta_{1-40}$, followed by $1 \mu \mathrm{M}$ or $10 \mu \mathrm{M} \mathrm{ZnCl}_{2}$ supplementation for $6 \mathrm{~h}$, respectively (Figure $5 \mathrm{~B}$ ). $\mathrm{ZnCl}_{2}$ supplementation for $6 \mathrm{~h}$ alone did not induce changes in synapse density, whereas $1 \mu \mathrm{M} \quad \mathrm{A} \beta_{1-40}$ treatment 


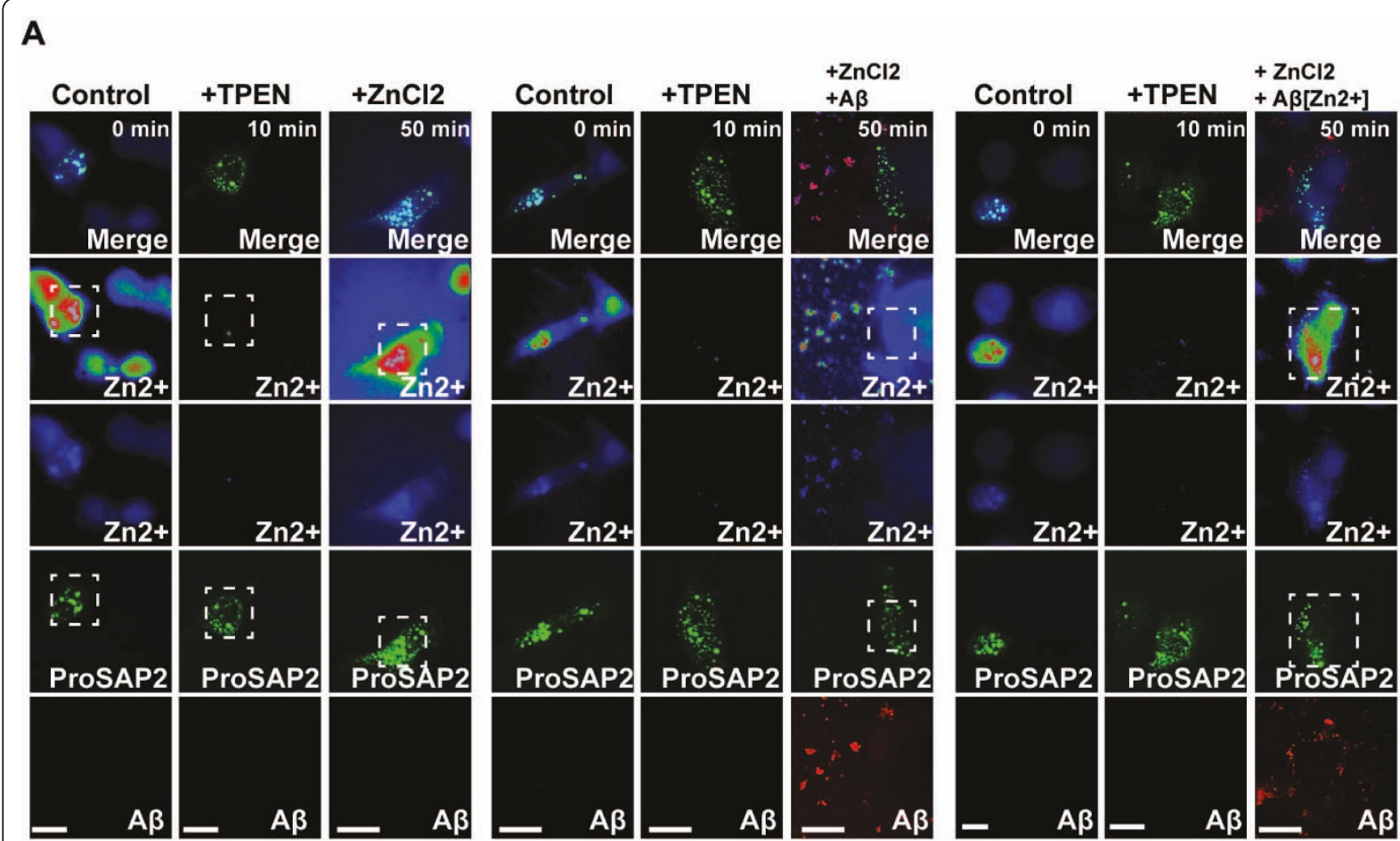

B

\section{C}
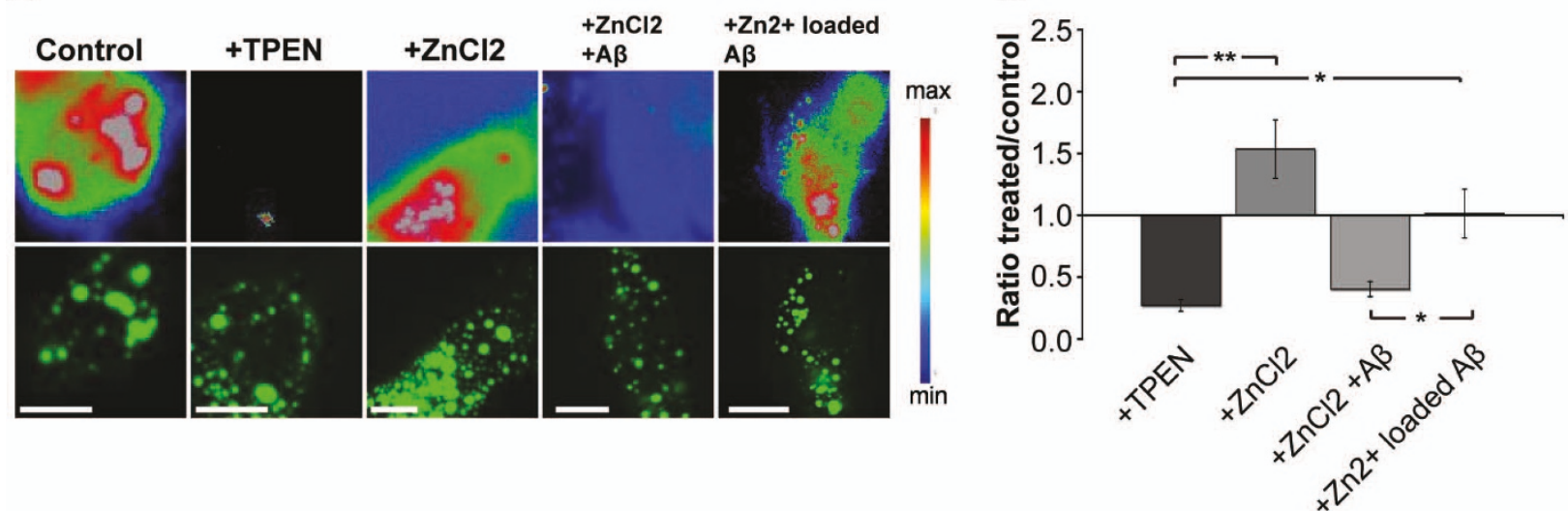

Figure $\mathbf{3}$ Application of soluble $\mathbf{A} \boldsymbol{\beta}$ oligomers decreases $\mathbf{Z n}^{\mathbf{2 +}}$ loading of ProSAP2/Shank3. Cos7 cells grown in $5 \mu \mathrm{M} Z \mathrm{n}^{2+}$-supplemented medium were transfected with GFP-ProSAP2/Shank3. The intracellular $\mathrm{Zn}^{2+}$ level, visualized by Zinquin ethyl ester, and subcellular distribution were compared to GFP-ProSAP2/Shank3. A) In control cells, GFP-ProSAP2/Shank3 colocalizes with $\mathrm{Zn}^{2+}$ ( $\mathrm{t}=0$ min) (left panel). After application of TPEN, $\mathrm{Zn}^{2+}$-ions were removed from ProSAP2/Shank3 clusters ( $\mathrm{t}=10 \mathrm{~min}$ ). Supplementation with $10 \mu \mathrm{M} \mathrm{ZnCl}_{2}$ restores and increases the initial $Z^{2+}$-association with GFP-ProSAP2/Shank3 clusters (left panel $t=50$ min). Twenty min application of $10 \mu M$ A $\beta_{1-40}($ red fluorescence) followed by supplementation with $10 \mu \mathrm{M} \mathrm{ZnCl} 2$ for 20 min only leads to a minor increase in $\mathrm{Zn}^{2+}$ loading of ProSAP2/Shank3 (middle panel $\mathrm{t}=$ 50 min). Application of $10 \mu \mathrm{M} \mathrm{A} \beta_{1-40}$ (red fluorescence) preloaded with $10 \mu \mathrm{M} \mathrm{ZnCl}$ followed by supplementation with $10 \mu \mathrm{M} Z \mathrm{ZnCl}$ leads to a significantly higher increase in ProSAP2/Shank3 $\mathrm{Zn}^{2+}$ loading (right panel $\mathrm{t}=50 \mathrm{~min}$ ) (scale bar $=50 \mu \mathrm{m}$ ). B) Magnification of $\mathrm{Zn}{ }^{2+}$ signals colocalizing with ProSAP2/Shank3 cluster under the conditions described in A) (scale bar $=25 \mu \mathrm{m}$ ). C) Quantification of $\mathrm{Zn}^{2+}$ fluorescence, visualized with Zinquin, colocalizing with ProSAP2/Shank3 clusters. The ratio of mean grey values between control cells ( $\mathrm{t}=0 \mathrm{~min}$ ) and treated cells is shown.

resulted in a significant reduction after 18 and $24 \mathrm{~h}$. However, supplementation of $\mathrm{ZnCl}_{2}$ for $6 \mathrm{~h}$ after $18 \mathrm{~h}$ treatment with $A \beta_{1-40}$, led to a significantly higher synapse density compared to cells treated with $A \beta_{1-40}$ alone. In fact, the synapse density after $\mathrm{ZnCl}_{2}$ supplementation was not significantly different from control (DMSO-treated) cells (Figure 5B).

To assess if $\mathrm{Zn}^{2+}$ supplementation or saturation of $\mathrm{A} \beta$ with $\mathrm{Zn}^{2+}$ is able to rescue ProSAP2/Shank3 levels at the synapse, we measured ProSAP2/Shank3 signal grey 

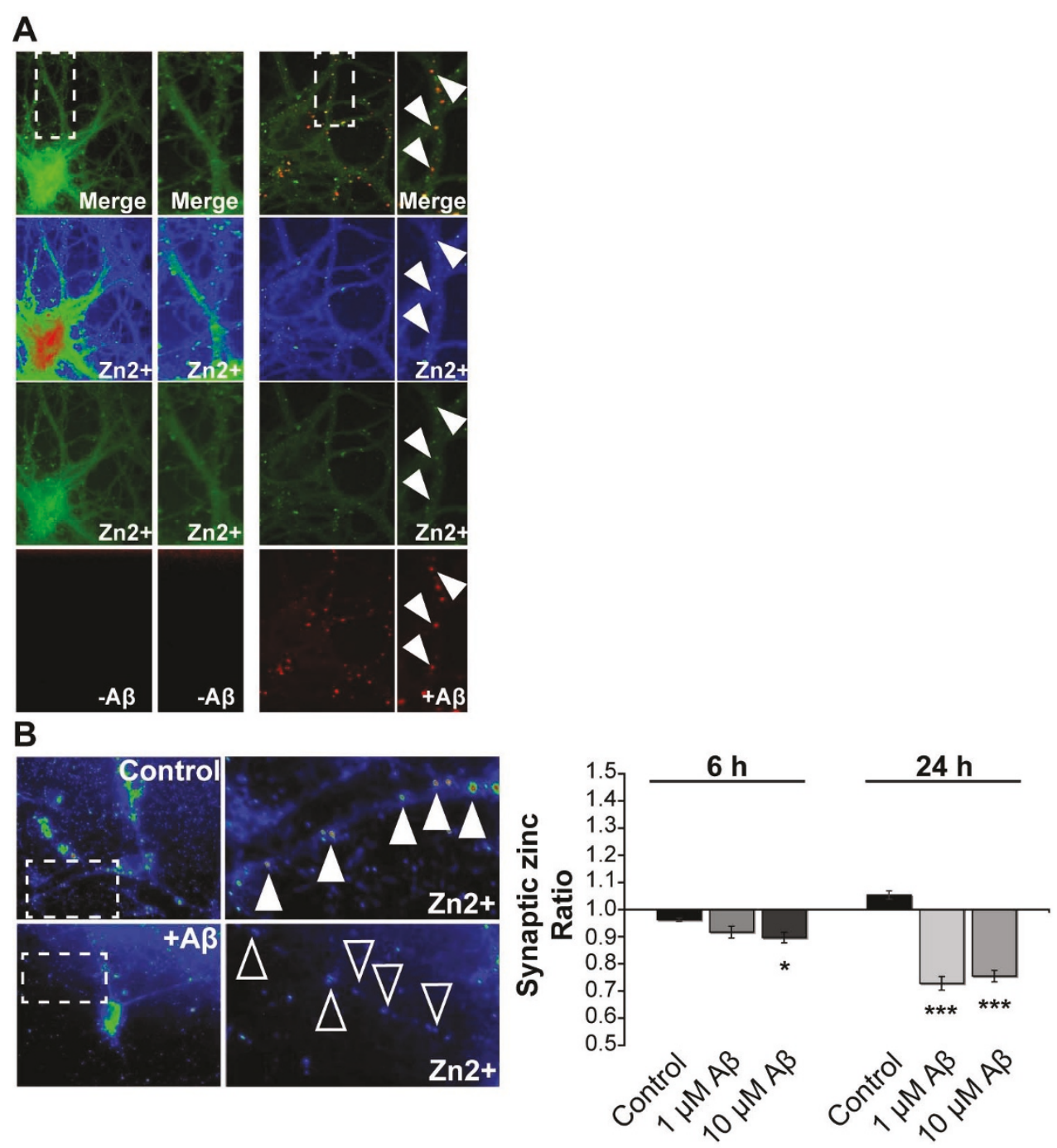

Figure 4 Intracellular $\mathrm{Zn}^{2+}$ levels are decreased in primary hippocampal culture neurons after treatment with soluble $A \beta$. A) In hippocampal cell cultures (DIV15), a fraction of applied $A \beta_{1-40}$ HiLyte FluorTM 555 can be found intracellular, after removal of extracellular $A \beta$ by washing steps, colocalizing with $\mathrm{Zn}^{2+}$ stained by Zinpyr-1 (arrows). B) After treatment of hippocampal neurons (DIV15) with $1 \mu \mathrm{M}$ and $10 \mu \mathrm{M}$ $A \beta_{1-40}$, a reduction in dendritic $Z^{2+}$ signals (arrows) can be seen. The mean grey value of Zinquin signals inside dendrites was measured from five cells and the ratio between cells treated for 6 or $24 \mathrm{~h}$ and untreated cells is shown. A significant reduction can be seen after $6 \mathrm{~h}(10 \mu \mathrm{M})$ and $24 \mathrm{~h}(1 \mu \mathrm{M}$ and $10 \mu \mathrm{M})$ treatment.

values under the conditions described above and performed Western Blot analysis of protein levels. The results show that after treatment for 1,6 and $24 \mathrm{~h}$, neither control (DMSO-supplemented) nor $1 \mu \mathrm{M} \mathrm{Zn^{2 }}$ ${ }^{+}$-supplemented neurons display any changes in ProSAP2/Shank3 levels at the synapse (Figure 5C, D, for loading control of Figure 5D see Additional file 4A). Treatment with $1 \mu \mathrm{M} \mathrm{A} \beta_{1-40}$ resulted in a significant decrease of ProSAP2/Shank3 levels after 6 and $24 \mathrm{~h}$ (Figure 5C) compared to control (DMSO treated) cells. However, $24 \mathrm{~h}$ treatment of hippocampal neurons with $1 \mu \mathrm{M} \mathrm{A} \beta_{1-40}$ preincubated for $1 \mathrm{~h}$ on ice with $1 \mu \mathrm{M}$
$\mathrm{ZnCl}_{2}$ led to significantly higher ProSAP2/Shank3 levels compared to treatment with $1 \mu \mathrm{M} A \beta_{1-40}$ alone (Figure $5 \mathrm{C}, \mathrm{E})$. Thus, $\mathrm{Zn}^{2+}$-saturated $\mathrm{A} \beta$ causes less decrease of ProSAP2/Shank3 protein levels at the synapse. Similar to the experiments described above, we investigated if supplementation of $\mathrm{Zn}^{2+}$ after $A \beta$ protein induced decrease in ProSAP2/Shank3 levels is able to rescue the effects of $A \beta$. To that end, we treated hippocampal neurons (DIV15) for $18 \mathrm{~h}$ with $1 \mu \mathrm{M}$ or $10 \mu \mathrm{M} \mathrm{A} \beta_{1-40}$, followed by $1 \mu \mathrm{M}$ or $10 \mu \mathrm{M} \mathrm{ZnCl}$ supplementation for 6 h (Figure $5 \mathrm{D}, \mathrm{E}) . \mathrm{Zn}^{2+}$ supplementation for $6 \mathrm{~h}$ alone did not induce changes in ProSAP2/Shank3 levels, 

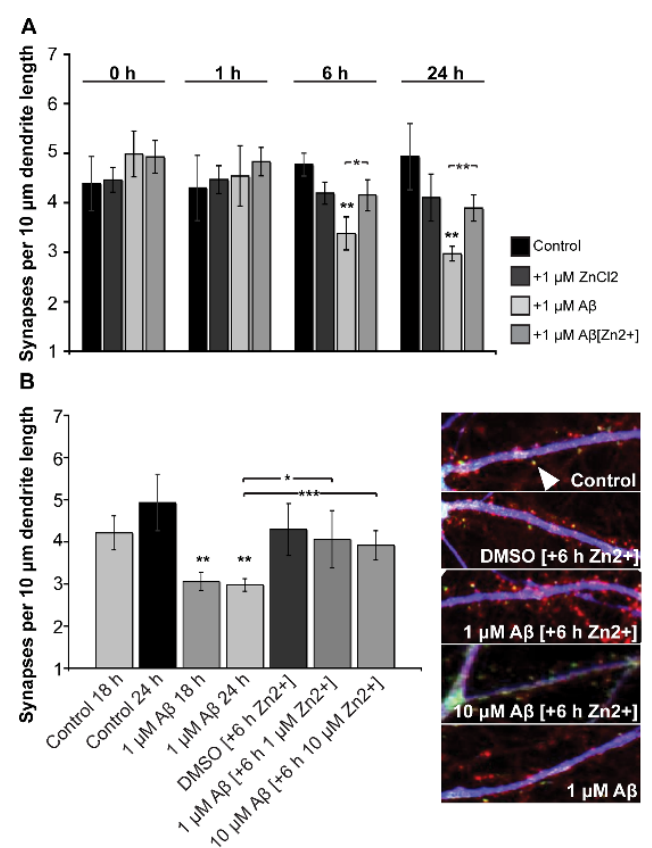

C

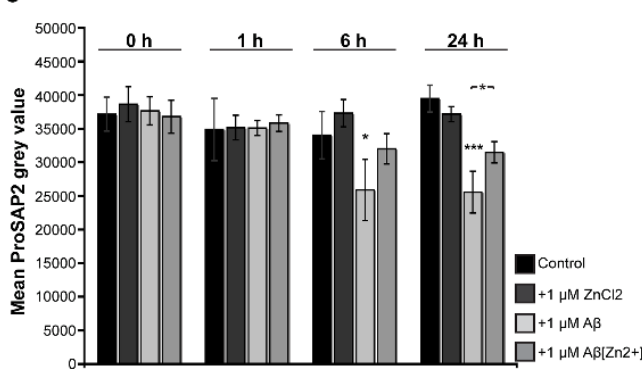

E

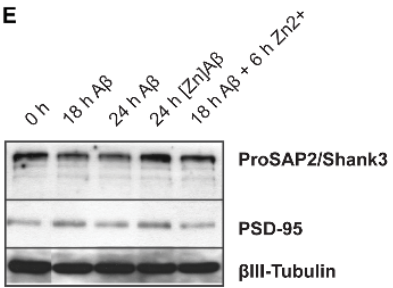

D

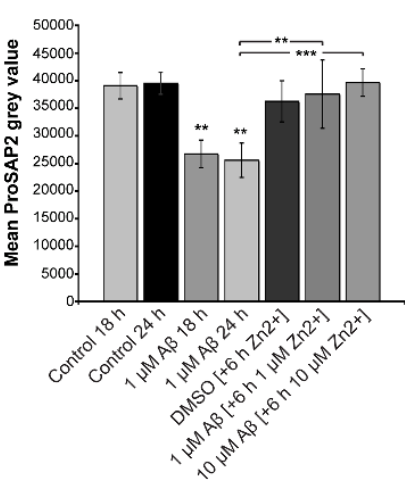

Figure $5 \mathrm{~A} \beta$ binding of $\mathrm{Zn}^{2+}$ regulates synapse loss and synaptic levels of ProSAP2/Shank3 in hippocampal cell culture. A,B) Effect of $\mathrm{A} \beta$ and $\mathrm{Zn}^{2+}$ on synapse density assessed by treating cultured hippocampal neurons (DIV15) with $\mathrm{A} \beta_{1-40}$ followed by equimolar $\mathrm{ZnCl} 2$ supplementation or $A \beta_{1-40}$ preincubated with equimolar $\mathrm{ZnCl}_{2}$. Synapse density was determined by quantifying the number of ProSAP2/Shank3 and Bassoon colocalizing puncta per unit length of MAP2 positive primary and secondary dendrites (arrow, right panel B). A) Quantification of synapse density on neurons treated for 1, 6 and $24 \mathrm{~h}$ with DMSO (control/vehicle), $1 \mu \mathrm{M} \mathrm{Zn}{ }^{2+}, 1 \mu \mathrm{M} \mathrm{A} \beta_{1-40}$ and $1 \mu \mathrm{M}$ A $\beta_{1-40}$ preincubated for 1 $\mathrm{h}$ on ice with $1 \mu \mathrm{M} \mathrm{ZnCl}_{2}$. B) Treatment of hippocampal neurons for 18 and $24 \mathrm{~h}$ with DMSO or A $\beta_{1-40}$, $18 \mathrm{~h}$ with DMSO and $6 \mathrm{~h}$ with $1 \mu \mathrm{M}$ $\mathrm{ZnCl}_{2}$ and $18 \mathrm{~h}$ with $1 \mu \mathrm{M}$ or $10 \mu \mathrm{M} \mathrm{A} \beta_{1-40}$, followed by $1 \mu \mathrm{M}$ or $10 \mu \mathrm{M} \mathrm{ZnCl}_{2}$ supplementation for $6 \mathrm{~h}$. Synapse density is significantly higher in cultures supplied with $A \beta$ saturated with $Z^{2+}$ than in those treated with $1 \mu \mathrm{M} A \beta_{1-40}$ alone. C,D) Synaptic levels of ProSAP2/Shank3 in hippocampal cultures treated with $\mathrm{Zn}^{2+}$ and/or A $\beta$ C) Quantification of ProSAP2/Shank3 signal grey values colocalizing with Bassoon puncta

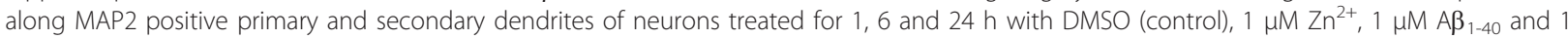
$\mu \mathrm{M} \mathrm{A} \beta_{1-40}$ preincubated for $1 \mathrm{~h}$ on ice with $1 \mu \mathrm{M} \mathrm{ZnCl}$. A significantly higher ProSAP2/Shank3 level compared to treatment with $1 \mu \mathrm{M} A \beta_{1-40}$ was measured after $24 \mathrm{~h}$ in cultures supplied with $\mathrm{Zn}^{2+}$-saturated $\mathrm{A} \beta \mathrm{D}$ ) Neurons treated for 18 and $24 \mathrm{~h}$ with DMSO or A $\beta_{1-40}, 18 \mathrm{~h}$ with DMSO and $6 \mathrm{~h}$ with $1 \mu \mathrm{M} \mathrm{ZnCl}$ and $18 \mathrm{~h}$ with $1 \mu \mathrm{M}$ or $10 \mu \mathrm{M} \mathrm{A} \beta_{1-40}$, followed by $1 \mu \mathrm{M}$ or $10 \mu \mathrm{M} \mathrm{ZnCl}$ supplementation for $6 \mathrm{~h}$. Supplementation of $\mathrm{ZnCl}_{2}$ for $6 \mathrm{~h}$ after $18 \mathrm{~h}$ treatment with $\mathrm{A} \beta_{1-40}$ leads to a rescue of ProSAP2/Shank3 levels at the synapse $\left(\mathrm{p}<0.05^{*} ;<0.01^{* *} ;<0.001^{* * *}\right)$. E) Western blots of P2 membrane fractions from hippocampal neurons cultured for 15 DIV and then treated for 18 or $24 \mathrm{~h}$ with $A \beta_{1-40}, 24 \mathrm{~h} A \beta_{1-40}$

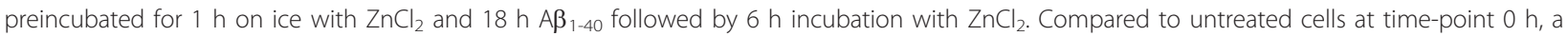
decrease in the amount of ProSAP2/Shank3 could be detected after 18 and $24 \mathrm{~h}$ of A $\beta$ treatment. In contrast, treatment for $24 \mathrm{~h}$ with $\mathrm{Zn}{ }^{2+}$ saturated $A \beta_{1-40}$ and $18 \mathrm{~h} \mathrm{~A} \beta_{1-40}$ followed by $6 \mathrm{~h}$ incubation with $\mathrm{ZnCl}_{2}$ leads to ProSAP2/Shank3 levels comparable to control conditions. Note PSD-95 and $\beta$-III Tubulin levels did not change under these conditions. 
whereas $1 \mu \mathrm{MA} \beta_{1-40}$, treatment resulted in a significant reduction. Supplementation of $1 \mu \mathrm{M}$ or $10 \mu \mathrm{M} \mathrm{ZnCl} 2$ for $6 \mathrm{~h}$ after $18 \mathrm{~h}$ treatment with $1 \mu \mathrm{M}$ or $10 \mu \mathrm{M} \mathrm{A} \beta_{1-40}$ respectively, led to a complete rescue of the decrease in ProSAP2/Shank3 levels (Figure 5D, E) and did not depend on enhanced protein synthesis (Additional file $4 \mathrm{~B})$. Interestingly, $\mathrm{Zn}^{2+}$ supplementation was also able to rescue synaptic Shank1 and partially, although not significantly, synaptic Homer1 levels (Additional file 4C).

Previous studies have demonstrated that the $\mathrm{A} \beta-\mathrm{Zn}^{2+}$ binding site is localized within residues $6-28$ and that histidines may serve as the principal sites of interaction [29], but interaction of $\mathrm{Zn}^{2+}$ with the full-length $A \beta_{1-40}$ and $A \beta_{1-42}$, as well as the truncated $A \beta_{1-16}$ and $A \beta_{1-28}$, were reported [30]. Thus, we used $A \beta_{29-40}$ as a control in our assays, because the C-terminus residues 29-40 do not seem to be affected by metal ion interactions [31]. The results showed that $A \beta_{29-40}$ does not significantly reduce synapse density within $24 \mathrm{~h}$ of treatment (Additional file 4D) nor does it significantly affect synaptic ProSAP2/Shank3 levels (Additional file 4E). We also investigated the amount of cell death after $A \beta_{1-40}, A \beta_{1-}$ 42 and $\mathrm{A} \beta_{29-40}$ treatment. Our data show similar toxicity with respect to cell death in hippocampal cell cultures. For example, at $48 \mathrm{~h}, \mathrm{~A} \beta_{1-40}, \mathrm{~A} \beta_{1-42}$ and $\mathrm{A} \beta_{29-40}$-treated cells showed signs of cell death (Additional file 4F), while no significant decrease in neuron number was seen after $24 \mathrm{~h}$ of treatment. This implies that cell death occurs independently from $\mathrm{Zn}^{2+}$ dysregulation.

\section{Altered $\mathrm{Zn}^{2+}$ and ProSAP/Shank levels in human AD and APP-PS1 mouse brain}

To assess whether an excess of $A \beta$ leads to alterations of $\mathrm{Zn}^{2+}$ levels in vivo, we visualized $\mathrm{Zn}^{2+}$ using Zinpyr-1 in hippocampal brain sections of APP-PS1 mice (3, 6 and 12 months of age) and AD patients. The brightness of the intracellular Zinpyr-1 fluorescence that correlates with local $\mathrm{Zn}^{2+}$ levels, was assessed (Figure 6A, 7A), as was the specificity of the signal by application of the $\mathrm{Zn}^{2+}$ chelator TPEN (Additional file 5). After treatment with TPEN, the Zinpyr-1 signals in the CA3/dentate gyrus regions of the hippocampus were eliminated (Additional file 5). A comparison of $\mathrm{Zn}^{2+}$ levels in the dentate gyrus and CA3 regions (Additional file 6) of wild type and APP-PS1 mice revealed a significantly lower $\mathrm{Zn}^{2+}$ staining in APP-PS1 mice beginning with 6 m.o.a. (Figure 6A). Moreover, extracellular $\mathrm{Zn}^{2+}$ ions were enriched in plaques formed by $A \beta$ (Figure $6 \mathrm{~A}$, arrows). These data are consistent with higher $A \beta$ levels causing a depletion of $\mathrm{Zn}^{2+}$ in the hippocampus of older APP-PS1 mice. To assess whether disease progression in APP-PS1 mice is associated with a reduction in synapse density and/or synaptic ProSAP/Shank levels, we stained hippocampal sections from APP-PS1 mice with antibodies against ProSAP2/Shank3 or Shank1 as well as Bassoon and VGluT. In these experiments, we observed a significant reduction in synapse density in brain sections of APP-PS1 mice at 12 m.o.a. (Figure 6B, C). Similarly, synaptic levels of ProSAP2/Shank3 and Shank1 were significantly decreased at this age (Figure 6B, D).

To assess whether patients with Alzheimer's Disease (AD) exhibit similar reductions in $\mathrm{Zn}^{2+}$ and ProSAP/ Shank levels in the hippocampus, we analyzed brain sections from 14 control and AD patients (Table 1). Human sections were divided into three groups based on their Clinical Dementia Rating (CDR), Mini-Mental State Examination (MMSE), and Braak scores: a) "control" sections, b) sections of patients with mild cognitive impairment "MCI" and c) patients with terminal/severe Alzheimer's disease "AD". Similar to the experiments conducted in APP-PS1 mice, we assessed intracellular $\mathrm{Zn}^{2+}$ concentration using Zinpyr-1 staining. The results show that sections from severely impaired $A D$ patients ("AD") display significantly lower $\mathrm{Zn}^{2+}$ staining (Figure 7A). Moreover, extracellular $\mathrm{Zn}^{2+}$ ions were enriched at plaques formed by $\mathrm{A} \beta$ (Figure 7B, arrows). These observations are again consistent with the capacity of $A \beta$ to bind, sequester and thus reduce intracellular $\mathrm{Zn}^{2+}$ levels in the hippocampus of $\mathrm{AD}$ patients.

To assess synapse density, we initially stained human hippocampal sections with antibodies against the presynaptic active zone protein Bassoon and the PSD protein Homer1. The number of Bassoon and Homer1 colocalizing puncta was then quantified per optic field (Figure $8 \mathrm{~A}$ ). This revealed a significant reduction in synapse number in brain sections of severe AD cases ("AD") compared to controls. To measure the change of ProSAP2/Shank3 and Shank1 at these synapses, the signal intensity of Alexa568-labeled ProSAP/Shank proteins opposed to a Bassoon or VGluT signal was measured (Figure 8B). Ten optical fields of 3 different sections per case were measured and the mean grey value per group calculated. The results showed a significant reduction of ProSAP2/Shank3 and Shank1 in the AD group compared to controls. Moreover, the clear trend towards this reduction could already be seen in "MCI" patient sections.

\section{Discussion}

Soluble $A \beta$ oligomers are thought to cause early synaptic damage and memory deficits in AD [32], although the mechanisms through which $A \beta$ aggregates might lead to this phenotype are not yet fully understood. During the progression of $\mathrm{AD}$, monomers of $\mathrm{A} \beta$ can aggregate to form amyloid fibrils. Five distinct fibrillar aggregates induced by $\mathrm{Zn}^{2+}$ have been described [33], including protofibrils, $A \beta$-derived diffusible ligands $(\mathrm{ADDL})$ and oligomeric species $[34,35]$. Oligomeric $\mathrm{A} \beta$ 


\section{A}

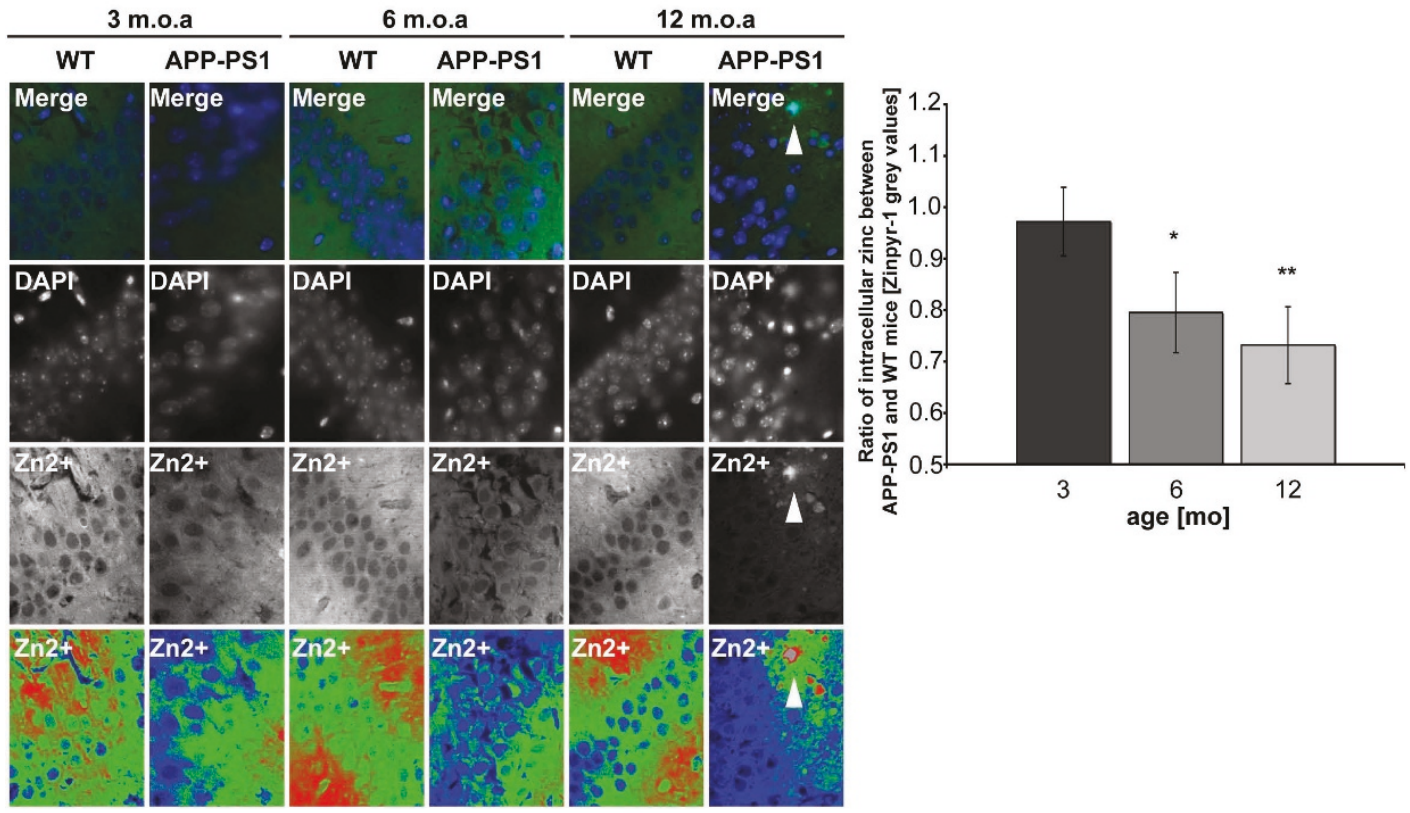

B
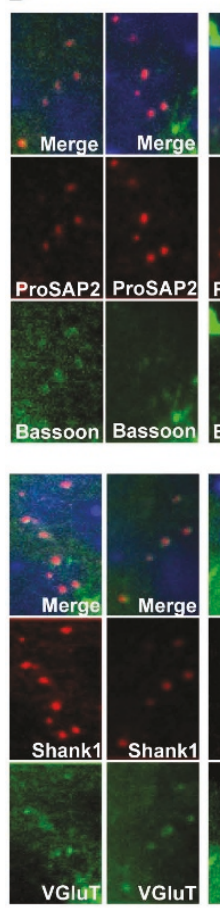
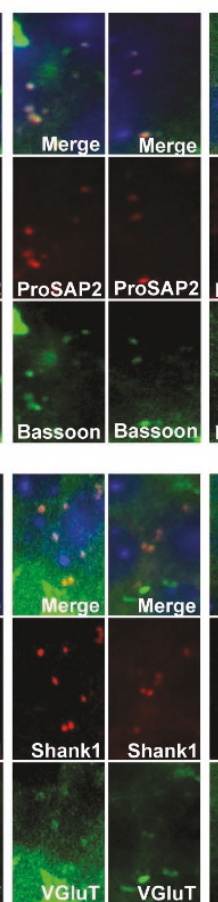

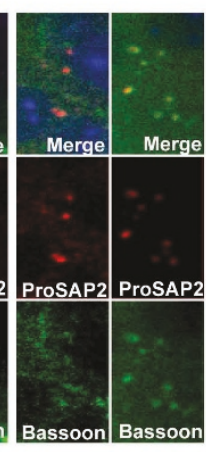

C
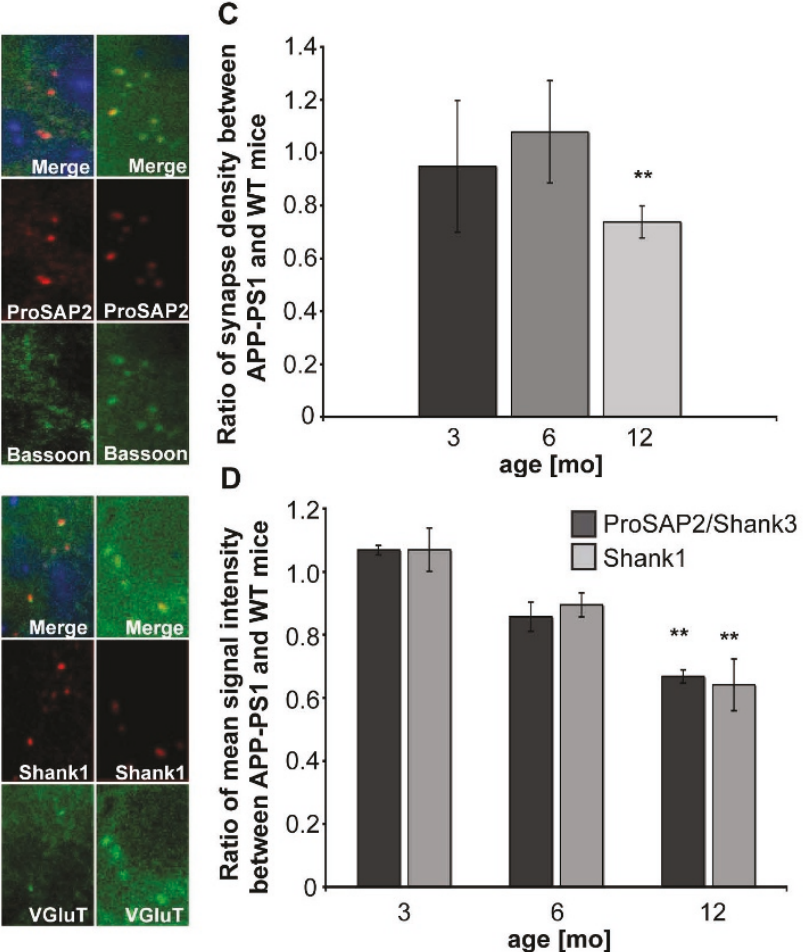

Figure 6 Synapse density, synaptic ProSAP2/Shank3 and intracellular $\mathrm{Zn}^{2+}$ levels are decreased in APP-PS1 mouse brain sections. A) Cellular $\mathrm{Zn}^{2+}$ levels are reduced in APP-PS1 hippocampus. Hippocampal sections from WT and APP-PS1 mice were double stained with DAPI to reveal cell nuclei and Zinpyr-1 to fluorescent-detect intracellular $\mathrm{Zn}^{2+}$ (see Figure S6). The ratio of mean Zinpyr-1 grey values between APP-PS1 and WT mouse sections at 3,6 and 12 months of age is shown. The intracellular zinc concentration is significantly decreased in sections from 6 and 12 month-old mice (right panel). An enrichment of $\mathrm{Zn}^{2+}{ }_{-}$-ions can be found colocalizing with extracellular A $\beta$ plaques (arrow). B,C) The total number of synapses per optic field was measured and the ratio of mean number of synapses per optic field between APP-PS1 and WT mice is shown. A significant decrease is visible at 12 months. B,D) Sections of APP-PS1 and WT mice were stained with anti-Bassoon or anti-VGluT antibody as presynaptic marker and ProSAP2/Shank3 or Shank1 antibodies, respectively. The mean signal intensity of Alexa568 labeled ProSAP/ Shank proteins opposed to a Bassoon or VGluT signal was measured and the ratio of mean grey values between APP-PS1 and WT mice is shown (merged images in B include DAPI staining (blue)). 
Table 1 Classification of human hippocampal brain sections

\begin{tabular}{|c|c|c|c|c|c|c|c|c|c|}
\hline Case & Case Code & Age & Gender & Pmi [h] & CDR & MMSE & BraakNFT & BraakNP & Diagnosis \\
\hline Control 1 & $99-111$ & 75 & $M$ & 6 & 0 & 29 & 1 & 1 & $C$ \\
\hline Control 2 & $00-96$ & 91 & W & 10 & 0 & 28 & 2 & 1 & $C$ \\
\hline Control 3 & $02-55$ & 82 & $M$ & 4.5 & 0 & 28 & 2 & 1 & $C$ \\
\hline Control 4 & $99-121$ & 82 & M & 7 & 0.5 & 26 & 1 & 1 & C \\
\hline $\mathrm{MCl} 1$ & $00-37$ & 90 & W & 4 & 0.5 & 28 & 2 & 1 & $\mathrm{MCl}$ \\
\hline $\mathrm{MCl} 2$ & 00-33 & 77 & W & 8 & 0.5 & 27 & 2 & 2 & $\mathrm{MCl}$ \\
\hline $\mathrm{MCl} 3$ & $00-61$ & 87 & W & 8 & 0.5 & 27 & 2 & 1 & $\mathrm{MCl}$ \\
\hline $\mathrm{MCl} 4$ & 99-105 & 85 & M & 4.5 & 0.5 & 20 & 3 & 1 & $\mathrm{MCl}$ \\
\hline AD 1 & $99-68$ & 88 & $M$ & 8 & 2 & 13 & 3 & 3 & $A D$ \\
\hline AD 2 & $00-58$ & 85 & $M$ & 6 & 2 & 20 & 4 & 2 & $A D$ \\
\hline AD 3 & 99-96 & 90 & $M$ & 2 & 2 & 10 & 6 & 3 & $A D$ \\
\hline AD 4 & 98-15 & 85 & W & 11 & 3 & 11 & 6 & 4 & $A D$ \\
\hline AD 5 & $99-67$ & 95 & W & 3 & 3 & 0 & 5 & 4 & $A D$ \\
\hline AD 6 & 99-98 & 102 & W & 11 & 3 & 0 & 6 & 4 & $A D$ \\
\hline
\end{tabular}

Hippocampal sections of human brains were used and classified as "Control", "MCl" and "AD" (m: man; w: woman; pmi: postmortem interval; CDR: Clinical Dementia Rating score; MMSE: Mini-Mental State Examination score; BraakNFT; neurofibrillary tangles Braak score; BraakNP: neuritic plaques Braak score; C: Control; MCI: mild cognitive impairment; AD: severe Alzheimer's disease).

peptides have the ability to form dimers, trimers, tetramers and higher-order arrays that can form so-called annular structures. These are thought to influence the functionality of cytoskeleton-associated proteins, cause damage to synaptic spines and inhibit long-term potentiation in cultured neurons [33,36,37] and in vivo [38]. It was shown that physiological levels of $\mathrm{Cu}^{2+}$ and $\mathrm{Zn}^{2+}$ cause $\mathrm{A} \beta$ to aggregate [39] and that $\mathrm{Zn}^{2+}$ ions are bound to $A \beta$ via the histidine imidazole rings within senile plaque cores [40]. Recently, Adlard et al. proposed a mechanism whereby $A \beta$ pathology causes cognitive impairment by trapping synaptic $\mathrm{Zn}^{2+}$ rather than through direct toxicity [41]. Thus, the transsynaptic movement of $\mathrm{Zn}^{2+}$ may be severely compromised in $\mathrm{AD}$ by being sequestered in $A \beta$. This trapping of $\mathrm{Zn}^{2+}$ might mimic ZnT3 ablation [41] and indeed, mice with a disruption of the vesicular $\mathrm{Zn}^{2+}$ transporter $\mathrm{ZnT3}$, display complete absence of $\mathrm{Zn}^{2+}$ from synaptic vesicles throughout the brain [42] as well as synaptic and memory deficits comparable to those seen in a cognitively impaired APP transgenic mouse model of AD [41].

Based on these findings, we propose a model, where $\mathrm{Zn}^{2+}$-ions might fail to reach their postsynaptic targets like ProSAP/Shank proteins due to sequestration by $A \beta$, leading to a dysregulation of the PSD scaffold and ultimately to a loss of synapses that can also be seen in ProSAP/Shank knockdown conditions [17]. This model is consistent with findings of Deshpande et al., who postulated that sequestration of $\mathrm{Zn}^{2+}$ in oligomeric $\mathrm{A} \beta$ leads to reduced availability of $\mathrm{Zn}^{2+}$ at the synapse, ultimately leading to cognitive deficits in $\mathrm{AD}$ [43]. To test this model, we investigated the influence of $A \beta_{1-40}$ and
A $\beta_{1-42}$ on ProSAP/Shank family members in hippocampal neuron culture. In line with a number of recent publications showing the possibility that $A \beta$ oligomers influence synaptic proteins and thus interfere with synaptic function $[7,12,13,44,45]$, our study shows that the synaptic levels of ProSAP2/Shank3 and Shank1 decrease significantly following the addition of $A \beta$ to primary neurons. Moreover, introduction of $A \beta$ oligomers leads to a significant reduction (about 25\%) in synapse density in hippocampal cultures, which is in agreement with previous studies reporting 11 to $77 \%$ declines in synaptophysin immunostaining in brain sections $[46,47]$. These results are also consistent with recent studies in cellular and rodent models, showing that small soluble oligomers are toxic because they directly damage synapses $[32,48]$. Furthermore, our experiments show that the loss of synapses is caused by a decrease in mature synapses. Thus, we conclude that the reduction in synapse density caused by $A \beta$ is due to impaired activity dependent maturation and destabilization of mature synapses, but leaves the ability of an initial formation of synapses intact.

Additionally, treatment of hippocampal neurons with $A \beta_{1-40}$ leads to a significant downregulation of ProSAP2/Shank3 at the synapse, to an impairment in synapse maturation and, in line with previous studies, to a downregulation of synaptic Shank1 levels [13]. The decrease in synaptic ProSAP2/Shank3 is also reflected by a decrease in protein levels in the $\mathrm{P} 2$ fraction as assessed by Western Blotting after $24 \mathrm{~h}$ treatment with $A \beta_{1-40}$. Given the multiple interaction partners of Pro$\mathrm{SAP} /$ Shank proteins at the synapse, it is likely that $A \beta$ 


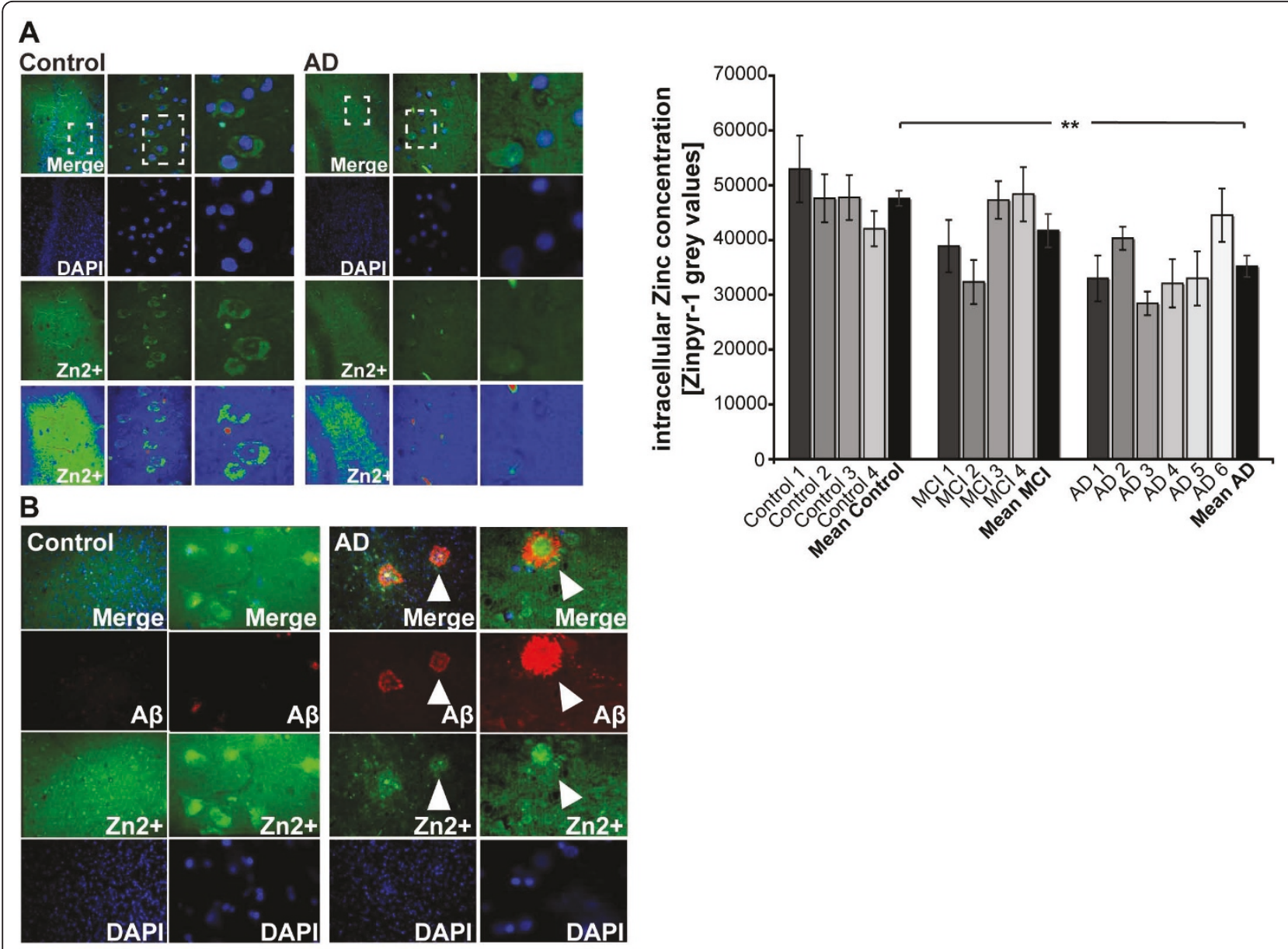

Figure $\mathbf{7}$ Intracellular $\mathbf{Z n}^{2+}$ levels are decreased in brain sections from AD cases. A) Zinc ions were visualized by Zinpyr-1 and the fluorescence of intracellular $\mathrm{Zn}^{2+}$ staining measured in AD patient and control sections (see Table 1). The mean Zinpyr-1 grey values of cells of 10 optical fields of view from $A D$ and Control cases are shown (a, right panel). The intracellular $\mathrm{Zn}^{2+}$ concentration is significantly decreased in sections of $\mathrm{AD}$ patients. B) Although the intracellular $\mathrm{Zn}^{2+}$ concentration is decreased in $\mathrm{AD}$, an enrichment of $\mathrm{Zn}{ }^{2+}$-ions can be found colocalizing with extracellular A $\beta$ plaques (arrow) in AD patient brain sections.

mediated changes in ProSAP/Shank complex formation cause synaptic dysfunction induced by reducing actin cytoskeletal assembly, spine motility as well as the maturation and plasticity of excitatory glutamatergic synapses.

We also show that the observed changes in ProSAP/ Shank levels at the synapse are not due to altered gene expression, proteasomal degradation or protein synthesis and it appears that other posttranscriptional mechanisms control synaptic ProSAP/Shank levels. One interesting candidate is $\mathrm{Zn}^{2+}$, which is known to bind and regulate the synaptic localization of specific ProSAP/ Shank family members, including ProSAP1/Shank2 and ProSAP2/Shank3 but not Shank1 [16-18]. We thus investigated whether an increased demand on extracellular $\mathrm{Zn}^{2+}$, e.g. by an increased level of $\mathrm{A} \beta$, would reduce cellular levels of $\mathrm{Zn}^{2+}$ and consecutively the synaptic levels of ProSAP/Shank family members. Using a cell- based assay, we directly demonstrated that the presence of extracellular $A \beta$ interferes with the proper loading of ProSAP2/Shank3 with $\mathrm{Zn}^{2+}$. In contrast, saturation of $\mathrm{A} \beta$ with $\mathrm{Zn}^{2+}$ before application does not change ProSAP2/Shank3 $\mathrm{Zn}^{2+}$ loading.

In hippocampal cell culture, exogenously applied $A \beta$ clusters with $\mathrm{Zn}^{2+}$ intracellular and treatment of cultured neurons with $\mathrm{A} \beta$ reduces dendritic $\mathrm{Zn}^{2+}$ levels. It was demonstrated previously that some intracellular $A \beta$ is derived from extracellular $\mathrm{A} \beta$ pools and several distinct pathways of entry for extracellular $A \beta$ have been proposed $[49,50]$. Although intracellular accumulation of $\mathrm{A} \beta$ is seen in multivesicular bodies and lysosomes, it can also be found within the cytosol [51]. Indeed, Kandimilla et al. have shown that $A \beta$ is internalized by neurons primarily via passive diffusion [49]. That way, a fraction of intracellular accumulating $A \beta$ might directly compete with $\mathrm{Zn}^{2+}$ binding proteins such as ProSAP2/Shank3 for 


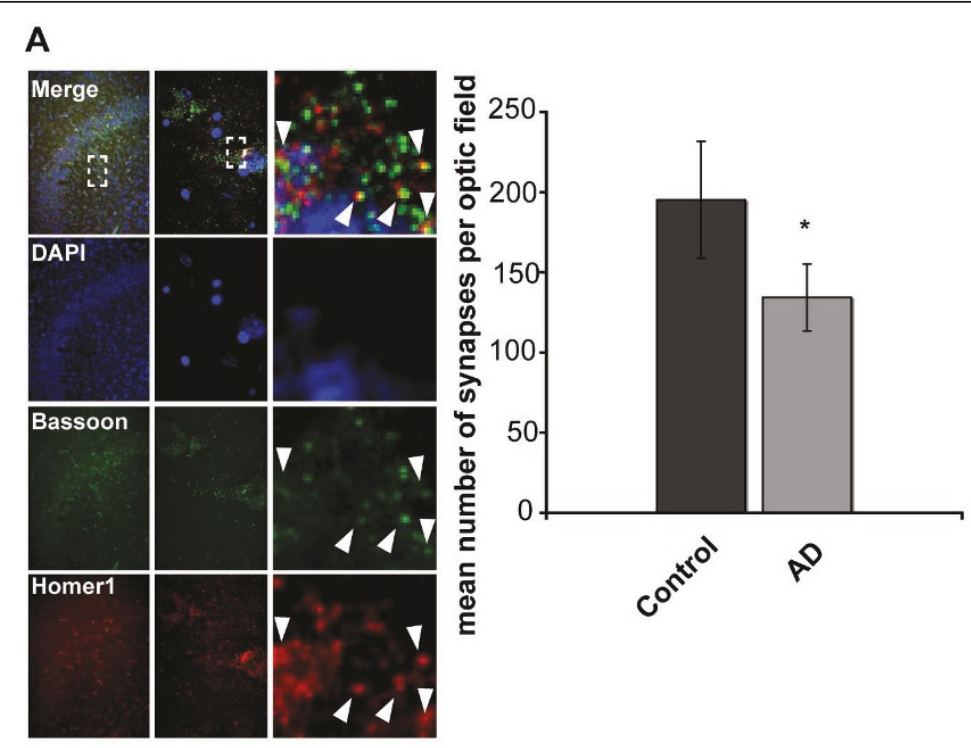

\section{B}
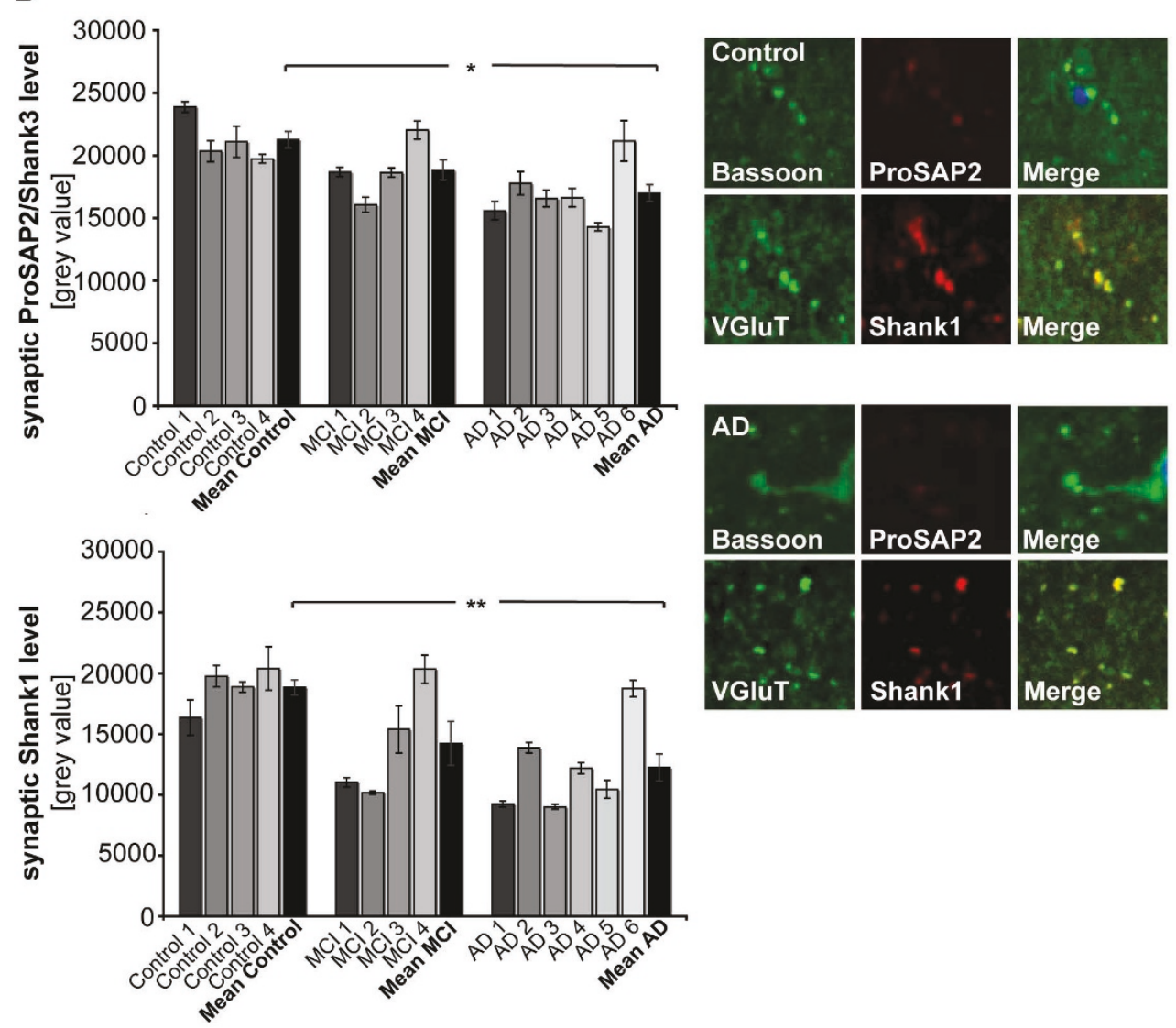

Figure 8 Synaptic ProSAP/Shank protein levels are reduced during AD progression in hippocampal brain sections. A) Immunofluorescent images of human hippocampal brain sections (CA3), stained with DAPI and antibodies against Bassoon and Homer1 (left panel) (low, medium and high magnification images are shown to reveal Bassoon/Homer1 co-clusters). The total number of synapses (colocalizing Bassoon/Homer1 puncta) was quantified to yield the mean number of synapses per optic field in control and patients with severe Alzheimer's disease (AD) (right panel). B) Loss of synaptic ProSAP2/Shank2 and Shank1 in AD patients was assessed by quantifying the intensity of ProSAP2/Shank3 and Shank1 puncta (mean grey values) colocalizing with Bassoon or VGluT (both presynaptic marker proteins) immunopositive puncta of hippocampal sections from control, "MCI" and "AD" patients. 
$\mathrm{Zn}^{2+}$ ions in addition to the sequestration of extracellular $\mathrm{Zn}^{2+}$ ions.

Based on these findings, we predicted that supplementation of hippocampal cultures with $\mathrm{Zn}^{2+}$ during the treatment with $A \beta$ or application of $\mathrm{Zn}^{2+}$-saturated $A \beta$ would lead to a rescue of the observed loss-of-ProSAP2/ Shank3 phenotype. Our results show that the $A \beta$ induced decrease in synapse density as well as lowered synaptic levels of ProSAP2/Shank3 can indeed be rescued by $\mathrm{Zn}^{2+}$-supplementation. Moreover, $\mathrm{Zn}^{2+}$ saturated $A \beta$ causes significantly less changes in synapse density and ProSAP2/Shank3 levels. Interestingly, also the decrease of Shank1 that shows a stronger requirement of NMDAR activity compared to ProSAP2/ Shank3, can be rescued by $\mathrm{Zn}^{2+}$-supplementation. This indicates that Shank1 scaffold plasticity might depend on both, homeostatic changes via ProSAP2/Shank3 and the presence of $\mathrm{Zn}^{2+}$ ions as well as on changes induced by synaptic activity, driven by the activation of downstream signaling pathways.

Our findings are further supported by in situ studies using APP-PS1 mice and AD patient brain sections. Here, we observed that $\mathrm{Zn}^{2+}$ ions are enriched within amyloid plaques present in the hippocampus of older APP-PS1 mice and patients with severe AD. Intriguingly, intracellular $\mathrm{Zn}^{2+}$ concentrations are $\sim 20 \%$ lower in neurons from these sections compared to control sections. However, in addition to the sequestration of $\mathrm{Zn}^{2+}$ by $A \beta$, other mechanisms may contribute to decreased intracellular $\mathrm{Zn}^{2+}$ concentrations, for example Metallothioneins (MTs) or other $\mathrm{Zn}^{2+}$-binding proteins such as $\alpha 2$ macroglobulin (A2M) [52] may alter levels by regulating intracellular free $\mathrm{Zn}^{2+}$. MT upregulation, as reported for MT-I in AD mouse models [53], leads to inhibition of NO-mediated $\mathrm{Zn}^{2+}$ release. Furthermore, pro-inflammatory cytokines cause a large induction of MTs [52]. Several $\mathrm{Zn}^{2+}$ transporter proteins, including $\mathrm{ZnT}-1, \mathrm{ZnT}-4$ and $\mathrm{ZnT}-6$, are altered in brain regions of subjects with early and late stages of AD [54]. Moreover, several members of the ZnT family (ZnT-1, 3, 4, 5, $6,7)$ are expressed in amyloid plaques [55].

In addition to reduced intracellular $\mathrm{Zn}^{2+}$ levels, we found a significant decrease in synapse density and synaptic ProSAP2/Shank3 and Shank1 protein levels. While chelation of $\mathrm{Zn}^{2+}$ by extracellular $A \beta$ appears a likely mechanism for influencing $\mathrm{Zn}^{2+}$ levels in the brain, it should be noted that intracellular chelation of $\mathrm{Zn}^{2+}$ might also contribute to its sequestration. Interestingly, it was recently found that serum $\mathrm{Zn}^{2+}$ concentrations were significantly reduced from $12.3 \mu \mathrm{mol} / \mathrm{l}$ to $10.9 \mu \mathrm{mol} / \mathrm{l}$ in AD patients compared to control subjects [56]. Moreover, $\mathrm{Zn}^{2+}$ supplementation greatly delays hippocampus-dependent memory deficits and strongly reduces both $A \beta$ and tau pathology in the hippocampus of an $\mathrm{AD}$ mouse model [57].
However, distinct mechanisms might contribute to the observed decreases in PSD scaffold proteins in a brain region specific manner. In cortical cultures, the A $\beta 1-40-$ mediated reduction of PSD-95 protein levels is dependent on NMDAR activity and cyclin-dependent kinase 5, involving the proteasomal pathway [14]. However, the decreased levels of Homer1b and Shank1 were not influenced by proteasome activity. The decreased levels of synaptic Homer1b required de novo protein synthesis and involved the PI3-K pathway and calcineurin phosphatase (PP2B) activity, whereas declustering of Shank1 required NMDAR activity and activation of the ERK pathway [13]. In this study, the focus on the hippocampal region and the use of primary cultured neurons derived from hippocampus might explain the differences in regulatory pathways and kinetics mediating decreased levels of PSD scaffold proteins. This is underlined by our results, showing that a downregulation of ProSAP2/ Shank3 and Shank1 in cortical neuronal cultures indeed occurs already after $1 \mathrm{~h}$ treatment with $\mathrm{A} \beta$ as reported previously [13]. Given that the hippocampus is the brain region with the highest $\mathrm{Zn}^{2+}$ concentration, $\mathrm{Zn}^{2+}$-dependent regulatory mechanisms of PSD plasticity might be more pronounced in the hippocampus compared to other brain regions.

Although sporadic forms of AD are the most common, mutations in presenilin are associated with familial AD causing approximately $50 \%$ of these cases. In fact, it was recently reported that presenilin is important for cellular copper and zinc turnover, having the potential to affect $A \beta$ aggregation indirectly through metal ion clearance [58]. Moreover, inflammatory processes that have been associated with AD [59] lead to a dysregulation of metallothioneins that might additionally sequester $\mathrm{Zn}^{2+}$. Thus, our experiments provide additional evidence for a common mechanism of the pathology of $\mathrm{AD}$ caused by the dysregulation of $\mathrm{Zn}^{2+}$ levels within the brain.

\section{Conclusions}

Based on our results and on recent studies [17], we conclude that $\mathrm{A} \beta$ complexes are able to bind extracellular and possibly also intracellular $\mathrm{Zn}^{2+}$, causing a dysregulation of $\mathrm{Zn}^{2+}$-dependent postsynaptic ProSAP/Shank scaffold proteins. Since ProSAP/Shank family members have specific roles in synapse formation and Shank1 is only targeted to a sufficiently preformed ProSAP1/ Shank2-ProSAP2/Shank3 scaffold [17], the synaptic loss of ProSAP2/Shank3 could lead to instable synapse formation and/or maturation. This could further ultimately result in the untimely elimination of synapses $[17,27]$ as evidenced by a reduction of Shank 1 at the PSD in A $\beta$ treated neurons and in patients with $\mathrm{AD}$. In terms of cognitive performance, this is expected to affect the 
establishment of new memory and the retention of older memories during disease progression.

Although the idea, that sequestration of $\mathrm{Zn}^{2+}$ by $\mathrm{A} \beta$ might cause the deficits seen in $A D$ has been raised in the past, our data provide the first mechanistic insights, that could ty the dysregulation of a major postsynaptic scaffold molecule to the depletion of $\mathrm{Zn}^{2+}$ by $\mathrm{A} \beta$ and consecutive synapse elimination.

\section{Methods}

\section{Chemicals and reagents}

Zinquin ethyl ester, $\mathrm{ZnCl}_{2}$, the $\mathrm{Zn}^{2+}$ chelators CaEDTA and TPEN ( $N, N, N$ ', $N$ '-tetrakis(2-pyridylmethyl)-ethylenediamine) were purchased from Sigma-Aldrich. Zinpyr-1 was purchased from Mellitech. Primary antibodies were purchased from Covance ( $\beta$-III Tubulin), Synaptic Systems (Homer1, PSD-95, VGluT), Novus Biologicals (Shank1 for IF), Stressgen (Bassoon), Sigma (PSD-95 for IF, Shank1 for WB) and Millipore $\left(A \beta_{1-40}\right.$ and $\left.A \beta_{1-42}\right)$. ProSAP2/Shank3 antibodies have been described previously [17]. Secondary Alexa-coupled antibodies were from Invitrogen. Unless otherwise indicated, all other chemicals were obtained from Sigma.

\section{Hippocampal cultures from rat brain}

The preparation of hippocampal cultures was performed essentially as described previously [60]. Cell culture experiments of hippocampal primary neurons from rat (embryonic day 18; E18) were performed as described previously [60]. After preparation, hippocampal neurons were seeded on poly-L-lysine $(0.1 \mathrm{mg} / \mathrm{ml}$; Sigma) glass coverslips. Cells were grown in Neurobasal medium (Invitrogen), complemented with B27 supplement (Invitrogen), $0.5 \mathrm{mM} \mathrm{L-Glutamine} \mathrm{(Invitrogen)} \mathrm{and} 100 \mathrm{U} /$ $\mathrm{ml}$ penicillin/streptomycin (Invitrogen) and maintained at $37^{\circ} \mathrm{C}$ in $5 \% \mathrm{CO}_{2}$. All animal experiments were performed in compliance with the guidelines for the welfare of experimental animals issued by the Federal Government of Germany and the National Institutes of Health. All of the experiments were conducted in strict compliance with APLAC approved animal protocols from Stanford University (protocol 14607) and by the local ethics committee at Ulm University (ID Number: O.103).

\section{Immunohistochemistry}

For immunofluorescence, the primary cultures were fixed with $4 \%$ paraformaldehyde (PFA)/1.5\% sucrose/1x PBS at $4^{\circ} \mathrm{C}$ for $20 \mathrm{~min}$ and processed for immunohistochemistry. After washing $3 \times 5$ min with $1 \mathrm{x}$ PBS at RT, blocking was performed with $0.5 \%$ cold fish gelatine (Sigma) and 0,1\% ovalbumin (Sigma)/1x PBS for $30 \mathrm{~min}$ at RT and the cells were washed again $3 \times 5$ min with $1 \mathrm{x}$ PBS at RT, followed by the primary antibody at $4^{\circ} \mathrm{C}$ overnight. After a $3 \times 5$ min washing-step with $1 \mathrm{x}$ PBS, incubation with the second antibody coupled to Alexa488, Alexa568 or Alexa647 for $1 \mathrm{~h}$ followed. The cells were washed again in $1 \mathrm{x}$ PBS for $10 \mathrm{~min}$ and 5 min with $\mathrm{dd}_{2} \mathrm{O}$ and mounted with Mowiol with or without DAPI (4',6-diamidino-2-phenylindole, for staining the nuclei) for fluorescence microscopy. Fluorescence images were obtained using an upright Axioscope microscope equipped with a Zeiss CCD camera (16 bits; $1280 \times 1024 \mathrm{ppi}$ ) using the Axiovision software (Zeiss) or a spinning disk confocal microscope from Zeiss with MetaMorph (Universal Imaging) software.

\section{Human sections}

Human brains from patients with different dementia severity were obtained from the autopsy service at the Department of Psychiatry from the University of Geneva, School of Medicine, Geneva, Switzerland. All procedures were reviewed and approved by the relevant Institutional Review Board and Ethics Committees. Details on the cases are provided in Table 1. Materials were fixed as full hemispheres in $4 \%$ paraformaldehyde for up to 6 weeks. Sections from hippocampal blocks were cut on a vibratome at a thickness of $50 \mu \mathrm{m}$ and kept as free-floating series in PBS-azide at $4^{\circ} \mathrm{C}$. For staining, sections were exposed to blocking solution, $10 \%$ BSA in $1 \mathrm{x}$ PBS for $1 \mathrm{~h}$ at room temperature and then incubated with the appropriate primary antibody in the blocking solution overnight at $4^{\circ} \mathrm{C}$. The sections were washed with buffer and incubated with the secondary antibody (1:1000) in blocking solution for $1 \mathrm{~h}$ at room temperature. Afterwards, sections were mounted in VectaShield (Vector Laboratories) with DAPI for confocal fluorescence microscopy.

\section{Mouse sections}

Animal studies were conducted in accordance with the National Institutes of Health guidelines for the use of experimental animals, and protocols were approved by the Institutional Animal Care and Use Committee. All mice were housed in an environment controlled for lighting (12-hour light/dark cycle), temperature, and humidity, with food and water available ad libidum. Male APP(swe)-PS1(dE9) mice, backcrossed for more than ten generations to a C57BL/6J background, were used for this study along with male non-transgenic littermates. At 3, 6, or 12 months of age, mice were deeply anesthetized and trans-cardially perfused with $0.9 \%$ saline. Brains were removed and fixed with $4 \%$ PFA in PBS for $24 \mathrm{~h}$ followed by immersion in 30\% sucrose in PBS for more than two days. Coronal brain sections $(40 \mu \mathrm{m})$ were prepared using a sliding microtome and used for immunostaining experiments as described above. 


\section{Biochemical Analysis}

To obtain P2/S2 fractions from hippocampal cultures, DIV15 cells exposed to different compounds of interest for the indicated times, were harvested and homogenized in homogenization buffer ( $320 \mathrm{mM}$ sucrose, 5 $\mathrm{mM}$ HEPES, $\mathrm{pH}$ 7.4) containing protease inhibitor mixture (Roche). Cell debris and nuclei were removed by centrifugation at $1000 \times \mathrm{g}$ for $15 \mathrm{~min}$. The supernatant was spun for $20 \mathrm{~min}$ at $12.0000 \times \mathrm{g}$ resulting in supernatant S2 (soluble fraction) and pellet P2 (membraneassociated fraction). Protein concentration was determined by amidoblack analysis and samples were further separated by SDS-PAGE, Coomassie-stained or blotted onto PVDF membranes using standard protocols. Immunoreactivity was visualized using HRP-conjugated secondary antibodies (DakoCytomation) and the SuperSignal detection system (Rockford).

\section{Treatment of hippocampal cells}

$\mathrm{A} \beta_{1-40}, A \beta_{1-42}$ (American Peptides), $A \beta_{29-40}$ peptide (VWR International) and labeled $A \beta_{1-40}(A \beta$ HiLyte Fluor ${ }^{\mathrm{TM}}$ 555-labeled, Anaspec) were prepared as described previously [13] and snap frozen at $-20^{\circ} \mathrm{C}$. As reported in several previous studies, the predominant aggregates in such preparations consist of low N-oligomers (mainly monomeric to tetrameric). Experiments were done with primary hippocampal neurons at DIV15-17 as indicated. Aliquots of $A \beta$ were diluted in culture medium to a final concentration of $1 \mu \mathrm{M}$ or 10 $\mu \mathrm{M}$ immediately before use.

To assess $A \beta$ cell toxicity, hippocampal DIV15 neurons were treated with $\mathrm{A} \beta_{1-40}\left(\mathrm{Ctrl},+1 \mu \mathrm{M} \mathrm{ZnCl}_{2}\right.$ or 1 $\mu \mathrm{M}$ CaEDTA), $A \beta_{1-42}$ and $A \beta_{29-40}$ for $48 \mathrm{~h}$ and fixed at time-points $0 \mathrm{~h}, 6 \mathrm{~h}, 24 \mathrm{~h}$ and $48 \mathrm{~h}$. The number of cells per optic field was determined counting DAPI positive nuclei and the number of neurons assessed by MAP2 staining. The mean of five different fields of view was calculated for each condition and time-point.

\section{Synapse measurements}

Pictures and were taken from neuronal synapses of hippocampal neurons with an upright Axioscope microscope equipped with a Zeiss CCD camera and a spinning disk confocal microscope from Zeiss. Quantification of fluorescence data was performed using MetaMorph (Universal Imaging), Image $J$ 1.44e for Macintosh, Axiovision and Noam Ziv's Openview software.

Statistical analysis in this paper was performed using Microsoft Excel for Macintosh and tested for significance using $t$ tests followed by ANOVA with an $\alpha$ level of significance set at $0.05\left(<0.05^{*} ;<0.01^{* * *} ;<0.001^{* * * *}\right)$. For evaluation, fluorescent puncta positive for a presynaptic marker (Bassoon, VGluT) and postsynaptic marker (ProSAP2/Shank3, Shank1, Homer1, PSD-95) along primary and secondary dendrites within the field of view were counted. Additionally, grey values and the signal area of post- and presynaptic proteins were measured and the results for the different conditions were evaluated in a blinded comparison. Pictures were all taken with the same acquisition time.

\section{Zinc staining}

Zinypr-1 was stored as a $5 \mathrm{M}$ stock solution in DMSO at $-20^{\circ} \mathrm{C}$. For cell culture neurons, growth medium was discarded and the cells were washed three times with HBBS. Hippocampal sections were incubated with a solution of $5 \mu \mathrm{M}$ Zinquin ethyl ester or Zinpyr-1 in HBSS for 30 min. Zinpyr- $1\left(\mathrm{C}_{46} \mathrm{H}_{36} \mathrm{Cl}_{2} \mathrm{~N}_{6} \mathrm{O}_{5}, \mathrm{MW}\right.$ : $823.22 \mathrm{~g}^{*} \mathrm{~mol}^{-1}$ ) is a membrane-permeant fluorescent sensor for $\mathrm{Zn}^{2+}$ with a high specificity and affinity for zinc $(\mathrm{Kd}=0.7 \pm 0.1 \mathrm{nM})$. Zinquin ethyl ester was stored as a $5 \mathrm{M}$ stock solution in DMSO at $-20^{\circ} \mathrm{C}$. Hippocampal neurons were incubated with a solution of $25 \mu \mathrm{M}$ Zinquin ethyl ester in HBSS for $20 \mathrm{~min}$ at $37^{\circ} \mathrm{C}[28]$.

\section{Cos7 cell assay}

Cos7 cells were maintained in Dulbecco's modified Eagle's medium (DMEM) with high glucose (Invitrogen), supplemented with $10 \%(\mathrm{v} / \mathrm{v})$ fetal calf serum, $2 \mathrm{mM} \mathrm{L-}$ glutamine and $5 \mu \mathrm{M} \mathrm{ZnCl}_{2}$. Cells were grown on commercially available chamber-slides (Nunc) treated with poly-L-lysine $(0.1 \mathrm{mg} / \mathrm{ml}$; Sigma). Transfection experiments with GFP-ProSAP2 (aa1-1806; full-size ProSAP2/ Shank3) were performed using the transfection-agent Lipofectamine 2000 (Invitrogen) according to the manufacturer's recommendations. At $16 \mathrm{~h}$ post-transfection, zinc-staining using Zinquin ethyl ester was performed ( $t$ $=0 \mathrm{~min}$ ) or cells were treated for $10 \mathrm{~min}$ with TPEN ( $\mathrm{t}$ $=10 \mathrm{~min}$ ) followed by either zinc-staining or application of $10 \mu \mathrm{M}$ fluorescent $A \beta_{1-40}$ ( $\beta$ HiLyte Fluor ${ }^{\mathrm{TM}} 555$ labeled) for $20 \mathrm{~min}$. After application of fluorescent $\mathrm{A} \beta_{1-40}$, an equimolar amount of $\mathrm{ZnCl}_{2}(10 \mu \mathrm{M})$ was supplemented for $20 \mathrm{~min}$ and subsequently, zinc-staining $(\mathrm{t}=50 \mathrm{~min})$ was performed; Alternatively, $10 \mu \mathrm{M}$ fluorescent $\mathrm{A} \beta$ preincubated for $1 \mathrm{~h}$ with $10 \mu \mathrm{M} \mathrm{ZnCl}$ was applied for $20 \mathrm{~min}$ followed by supplementation of $10 \mu \mathrm{M} \mathrm{ZnCl}$ for $20 \mathrm{~min}$ and subsequent zinc staining. After this, cells were fixed with 4\% PFA and mounted in VectaShield without DAPI.

\section{Quantitative Real-time PCR}

Isolation of total RNA from primary neuronal cell cultures was performed using the RNeasy kit as described by the manufacturer. Isolated RNA was eluted in a total of $20 \mu \mathrm{l}$ RNase-free water (supplied with the kit) and stored at $-80^{\circ} \mathrm{C}$. 
For the reverse transcriptase-mediated PCR studies, first strand synthesis and real-time quantitative RT-PCR amplification were carried out in a one-step, single-tube format using the QuantiFast SYBR Green RT-PCR kit. Thermal cycling and fluorescent detection were performed using the Rotor-Gene-Q real-time PCR machine (model 2-Plex HRM) (Qiagen). The qRT-PCR was assayed in $0.1 \mathrm{ml}$ strip tubes in a total volume of $20 \mu \mathrm{l}$ reaction mixture containing $1 \mu \mathrm{l}$ of undiluted total RNA, $2 \mu \mathrm{l}$ of QuantiTect Primer Assay oligonucleotides, $10 \mu \mathrm{l}$ of $2 x$ QuantiFast SYBR Green RT-PCR Master Mix supplemented with ROX (5carboxy-X-rhodamine) dye, $6.8 \mu \mathrm{l}$ of RNase-free water (supplied with the kit) and $0.2 \mu \mathrm{l}$ of QuantiFast RT Mix. RT. Amplification conditions were as follows: $10 \mathrm{~min}$ at $50^{\circ} \mathrm{C}$ and $5 \mathrm{~min}$ at $95^{\circ} \mathrm{C}$, followed by 40 cycles of PCR for $10 \mathrm{~s}$ at $95^{\circ} \mathrm{C}$ for denaturation, $30 \mathrm{~s}$ at $60^{\circ} \mathrm{C}$ for annealing and elongation (one-step). During the extension real-time fluorescence measurements were recorded by the PCR machine, thus monitoring real-time PCR amplification by quantitative analysis of the fluorescence emission. The SYBR Green I reporter dye signal was measured against the internal passive reference dye (ROX) to normalize non-PCR-related fluctuations in fluorescence which occurs from reaction tube to reaction tube. Resulting data were analysed utilizing the hydroxymethylbilane synthase gene as an internal standard to normalize transcript levels. Cycle threshold (ct) values were calculated by the RotorGene-Q Software (version 2.0.2). Cycle threshold values indicate the PCR cycle number at which the measured fluorescence of the indicator dye (SYBR Green I), accordant to the quantity of amplified PCR products, is increasing in a linear fashion above background. All qRT-PCR reactions were run in duplicates in three independent experiments and mean ct values for each reaction were taken into account for calculations of data analysis. To ascertain primer specificity a melting curve was obtained for the amplicon products to determine their melting temperatures. Melting curve was driven from $60^{\circ} \mathrm{C}$ to $95^{\circ} \mathrm{C}$ rising in $1^{\circ} \mathrm{C}$ steps while fluorescence was recorded continuously. For negative controls and to check for reagent contamination a complete reaction mixture was used in which the RNA sample was replaced by RNasefree water. Real-time quantitative PCR was carried out using oligonucleotides allowing to investigate expression of the following genes: Shank1 and ProSAP2/Shank3 (validated primer pairs, Quantitect primer assay, Qiagen). All consumables used for the extraction of total RNA and real-time PCR analysis were purchased from Qiagen.

\section{Additional material}

Additional file 1: Synapse number and protein composition of neurons treated with $A \beta_{1-42}$. Hippocampal neurons (DIV15) were treated with $1 \mu \mathrm{M} A \beta_{1-42}$ (soluble oligomers) and fixed after 0,6 , and 24 h. Immunocytochemistry was performed using anti-ProSAP2/Shank3 with anti-Bassoon as presynaptic marker. Images were taken with the same acquisition time and the mean grey value and mean area of ProSAP/ Shank signals opposite Bassoon signals was measured. A) The synapse density was calculated measuring the number of synapses per unit dendrite length of ten cells of three independent experiments for every time-point and condition. The ratio of the mean synapse density between treated and untreated neurons shows a significant decrease in synapse density starting at $6 \mathrm{~h}$ exposure to $A \beta_{1-42}$. B) The ratio of mean grey values between treated and untreated neurons shows a significant downregulation of ProSAP2/Shank3 at the synapse after $24 \mathrm{~h}$ treatment with $A \beta_{1-42}$. C) Cultured hippocampal neurons were immunostained with antibodies against Homer1 and PSD-95 and the ratio of mean grey values between treated and untreated neurons was measured after $0 \mathrm{~h}$, $1 \mathrm{~h}$ and $24 \mathrm{~h}$ treatment with $A \beta_{1-40}$. A significant decrease is seen after $24 \mathrm{~h}$ of treatment. D) The mean signal intensity of Homer1, ProSAP2/ Shank3 or Shank1 signals opposite Bassoon puncta was measured at time-point $0 \mathrm{~h}, 1 \mathrm{~h}$ and $24 \mathrm{~h}$ after $\mathrm{A} \beta_{1-40}$-treatment of cortical neurons. The ratio of signal intensity between treated and untreated synapses is shown. A decrease of ProSAP2/Shank3 and Shank1 levels can be seen as early as $1 \mathrm{~h}$ after treatment. E) The mean area of ProSAP2/Shank3 or Shank1 signals opposite Bassoon puncta was measured after $A \beta_{1-40^{-}}$ treatment. The change in the ratio of mean grey values per mean area between treated and untreated synapses (see Figure 1C) is based on a change in grey values, since the mean signal area is found to be the same for all time-points and conditions. The results show no significant changes between treated and untreated neurons. F) ProSAP2/Shank3 levels in immature vs. mature spines was measured using fluorescence grey values after $24 \mathrm{~h} \mathrm{~A} \beta_{1-40}$ treatment and compared to control conditions (24 h treatment with DMSO). Fluorescence grey values were normalized against presynaptic marker (Bassoon) grey values. Immature synapses show lower levels of ProSAP2/Shank3, increasing from filopodia-like to thin and mushroom/stubby spines. Treatment with $A \beta_{1}$. 40 significantly decreases the amount of ProSAP2/Shank3 in all spine types (significance indicated for comparison between "filopodia like" and "filopodia like after treatment", "thin" and "thin after treatment" etc.).

Additional file 2: Evaluation of PSD proteins after $A \beta_{1-40}$ treatment. A) Western blots of $\mathrm{S} 2$ soluble fractions from hippocampal neurons cultured for $15 \mathrm{DIV}$ and then treated for $6 \mathrm{~h}$ and $24 \mathrm{~h}$ with $A \beta_{1-40}(\mathrm{P} 2$ fractions presented in Figure 2A). Compared to untreated cells at timepoint 0 , no decrease in the amount of ProSAP2/Shank3 and Shank1 could be detected after $6 \mathrm{~h}$ or $24 \mathrm{~h}$ of A $\mathrm{A}$-treatment. Note, Homer 1 and PSD-95 levels did not change. Lysates from 3 independent experiments were quantified via Western Blot analysis by measuring the integrated density. The values were normalized against $\beta$-III Tubulin and $0 \mathrm{~h}$ was set to $100 \%$. B) The reduction of ProSAP2/Shank3 and Shank1 at the synapse is independent of both, proteasomal degradation and protein synthesis, since treatment with the proteasome inhibitor MG132 and protein synthesis inhibitor $\mathrm{CHX}$ did not prevent $A \beta_{1-40}$ induced changes in synaptic signal intensities of ProSAP2/Shank3 and Shank1. MK801, a NMDAR antagonist showed a tendency to prevent $A \beta_{1-40}$ induced changes in ProSAP2/Shank3 (although statistically not significant), but significantly decreased the amount of $A \beta_{1-40}$ induced changes in Shank1 levels. The ratio between two sets of untreated control cells is shown and compared to the ratio between cells treated with $A \beta$ and untreated cells as well as cells treated with MG132, CHX or MK801 in presence of $A \beta$ and cells treated with MG132, CHX or MK801 alone.

Additional file 3: Zinquin signals of neurons treated with $A \beta_{1-40}$. A) Zinquin ethyl ester detects synaptic $\mathrm{Zn}^{2+}$ signals. Co-labeling with FM dye reveals that the $\mathrm{Zn}^{2+}$ staining is mostly opposed to $\mathrm{FM}$, thus marking postsynaptic compartments. B) After treatment of hippocampal neurons with $1 \mu \mathrm{M}$ and $10 \mu \mathrm{M} A \beta_{1-40}$, a reduction in dendritic $\mathrm{Zn}^{2+}$ signal area above a fixed fluorescent threshold can be seen. The mean area of Zinquin signals above a fluorescence limit was measured from five cells and the ratio between cells treated for 6 or $24 \mathrm{~h}$ and untreated cells is shown. A significant reduction can be seen after $6 \mathrm{~h}(10 \mu \mathrm{M})$ and $24 \mathrm{~h}(10 \mu \mathrm{M})$ treatment.

Additional file 4: Zinc supplementation experiments in vitro. A) Coomassie staining, showing that similar amounts of protein were loaded for the quantification of changes in synaptic protein levels by 
Western blot analysis presented in Figure 5E. B-D) Hippocampal neurons (DIV15) were treated with $1 \mu \mathrm{M} \mathrm{A} \beta_{29-40}$ and fixed after 0, 6, and $24 \mathrm{~h}$. Immunocytochemistry was performed using anti-ProSAP2/Shank3 with anti-Bassoon as presynaptic marker. Images were taken with the same acquisition time and the mean grey value and mean area of ProSAP/ Shank signals opposite Bassoon signals was measured. B) Effect of A $\beta$ and $\mathrm{Zn}^{2+}$ on ProSAP2/Shank3 levels are independent of protein synthesis. Cultured hippocampal neurons were immunostained with antibodies against ProSAP2/Shank3 and the ratio of mean grey values between treated and untreated neurons was measured after $24 \mathrm{~h}$ treatment with $A \beta_{1-40}$ or $A \beta_{1-40}$ with equimolar $\mathrm{ZnCl}_{2}$ supplementation (see Figure 5) with and without application of the protein synthesis inhibitor $\mathrm{CHX}(15 \mu \mathrm{M})$. The presence of $\mathrm{CHX}$ does not prevent rescue of ProSAP2/Shank3 levels by $\mathrm{ZnCl}_{2}$ supplementation. C) Cultured hippocampal neurons (DIV 15) were immunostained with antibodies against Shank1 and Homer 1 and the ratio of mean grey values between treated and untreated neurons was measured after $24 \mathrm{~h}$ treatment with $A \beta_{1-40}$ or $A \beta_{1-40}$ with equimolar $\mathrm{ZnCl}$, supplementation (see Figure 5). $\mathrm{ZnCl}_{2}$ supplementation leads to a significant increase in Shank1 signal intensity at the synapse. Although Homer1 levels are also increased, there is still a significant difference to control cells and no statistically significant difference to $A \beta$ treated cells. D) The synapse density was calculated measuring the number of synapses per unit dendrite length of ten cells of three independent experiments for every time-point and condition. The ratio of the mean synapse density between treated and untreated neurons shows no significant decrease in synapse density. E) The ratio of mean grey values between treated and untreated neurons shows no significant downregulation of ProSAP2/Shank3 at the synapse after $24 \mathrm{~h}$ treatment with $A \beta_{29-40}$. F) Hippocampal neurons (DIV15) were treated with $A \beta_{1-40} A \beta_{1-42}$ and $A \beta_{29-40}$ and fixed after 0,6 , and $24 \mathrm{~h}$. The number of cells per optic field was identified by DAPI staining of nuclei and labeling of neurons by MAP2. No significant reduction is seen after $24 \mathrm{~h}$ (magnification of typical field of view of $A \beta_{1-40}$ treated neurons, right panel) (scale bar $=200 \mu \mathrm{m})$. G) However, after $48 \mathrm{~h}, A \beta_{1-40} A \beta_{1-42}$ and $A \beta_{29-40}$ treated neurons show signs of cell death (arrows, magnification of typical field of view of $A \beta_{1-40}$ treated neurons, right panel). Supplementation of cultures with $1 \mu \mathrm{M} \mathrm{ZnCl}_{2}$ or zinc depletion using the cell impermeable $\mathrm{Zn}^{2+}$ chelator CaEDTA did not lead to any changes in the amount of cell death (scale bar $=200 \mu \mathrm{m}$ ).

Additional file 5: Zinpyr-1 staining of human brain sections. $\mathrm{Zn}^{2+}$ ions were visualized by Zinpyr-1 in human (and mouse, data not shown) brain sections and the fluorescence of intracellular $\mathrm{Zn}^{2+}$ staining measured in control sections with and without application of TPEN prior to $\mathrm{Zn}^{2+}$ staining. The fluorescence of the Zinpyr-1 dye is mostly absent in TPEN-treated section revealing the high specificity of the $\mathrm{Zn}^{2+}$-staining in brain sections.

Additional file 6: Zinpyr-1 staining of APP-PS1 mouse hippocampal brain sections. $\mathrm{Zn}^{2+}$ ions were visualized by Zinpyr-1 and the fluorescence of intracellular $\mathrm{Zn}^{2+}$ staining measured in APP-PS1 mouse hippocampal brain sections from dentate gyrus (dg) and CA3 region in mice 3, 6 and 12 m.o.a (Inset on the upper right: $p=$ pyramidal cells, $g=$ granule cells).

\section{Acknowledgements}

MJS and PTU were supported by a thesis grant from UIm University, International Graduate School Molecular Medicine. AMG was supported by a fellowship from the Deutsche Forschungsgemeinschaft (DFG) and the NIH (P01 NS053862; R21 MH091471 to CCG). PRH and JDB were supported by $\mathrm{NIH}$ grant P50 AG05138. KIH was supported by NIH grant R01 AG03020901A2, TMB by the DFG (Bo 1718/3-1; SFB 497/B8). The authors thank Dr C. Bouras for generous provision of human brain materials and B. Wicinski for expert technical assistance.

\section{Author details}

'Institute for Anatomy and Cell Biology, Ulm University, Albert Einstein Allee 11, Ulm, 89081, Germany. ${ }^{2}$ Department of Psychiatry and Behavioral Sciences, Stanford School of Medicine, Stanford University, 1201 Welch Road, Stanford, CA 94305-5485, USA. ${ }^{3}$ Department of Neurology and Neurological
Sciences, Stanford School of Medicine, Stanford University, 300 Pasteur Drive, Stanford, CA 94305 USA. ${ }^{4}$ Fishberg Department of Neuroscience, Mount Sinai School of Medicine, One Gustave L. Levy Place, New York, NY 10029, USA. ${ }^{5}$ Friedman Brain Institute, Mount Sinai School of Medicine, One Gustave L. Levy Place, New York, NY 10029, USA. ${ }^{6}$ Department of Psychiatry, Mount Sinai School of Medicine, One Gustave L. Levy Place, New York, NY 10029, USA. ${ }^{7}$ Department of Genetics and Genomic Science, Mount Sinai School of Medicine, One Gustave L. Levy Place, New York, NY 10029, USA.

\section{Authors' contributions}

AMG and MJS designed the outline of this study and carried out all experiments in cell culture together with MS. MJS and PTU performed the biochemical and qRT-PCR analysis. AMG performed the staining of human and mouse brain sections. PRH provided human, KIA and NSW provided mouse-brain sections and participated with JDB and TMB in the design and coordination of the study. AMG and MJS performed all data analysis and jointly drafted the manuscript with MA, PRH, JDB, CCG and TMB. All authors read and approved the final version. AMG and MJS contributed equally to this study.

\section{Competing interests}

The authors declare that they have no competing interests.

Received: 13 May 2011 Accepted: 22 September 2011

Published: 22 September 2011

\section{References}

1. Hamos JE, DeGennaro $\sqcup$, Drachman D: Synaptic loss in Alzheimer's disease and other dementias. Neurology 1989, 39(3):355-361.

2. Terry RD, Masliah E, Salmon DP, Butters N, DeTeresa R, Hill R, Hansen LA, Katzman R: Physical basis of cognitive alterations in Alzheimer's disease: synapse loss is the major correlate of cognitive impairment. Ann Neurol 1991, 30:572-580.

3. DeKosky ST, Scheff SW, Styren SD: Structural correlates of cognition in dementia: quantification and assessment of synapse change. Neurodegeneration 1996, 5:417-421.

4. Selkoe D: Amyloid $\beta$ protein precursor and the pathogenesis of Alzheimer's disease. Cell 1989, 58:611-612.

5. Selkoe D: Physiological production of the $\beta$-amyloid protein and the mechanisms of Alzheimer's disease. Trends Neurosci 1993, 16:403-409.

6. Sisodia SS, Price DL: Role of the beta-amyloid protein in Alzheimer's disease. FASEB J 1995, 9:366-370

7. Pham E, Crews L, Ubhi K, Hansen L, Adame A, Cartier A, Salmon D, Galasko D, Michael S, Savas JN, Yates JR, Glabe C, Masliah E: Progressive accumulation of amyloid-beta oligomers in Alzheimer's disease and in amyloid precursor protein transgenic mice is accompanied by selective alterations in synaptic scaffold proteins. FEBS / 2010, 277:3051-3067.

8. Grabrucker AM, Schmeisser MJ, Schoen M, Boeckers TM: Postsynaptic ProSAP/Shank scaffolds in the cross-hair of synaptopathies. Trends Cell Biol 2011.

9. Durand CM, Betancur C, Boeckers TM, Bockmann J, Chaste P, Fauchereau F, Nygren G, Rastam M, Gillberg IC, Anckarsäter H, Sponheim E, GoubranBotros H, Delorme R, Chabane N, Mouren-Simeoni MC, de Mas P, Bieth E, Rogé B, Héron D, Burglen L, Gillberg C, Leboyer M, Bourgeron T: Mutations in the gene encoding the synaptic scaffolding protein SHANK3 are associated with autism spectrum disorders. Nat Genet 2007, 39(1):25-27.

10. Moessner R, Marshall CR, Sutcliffe JS, Skaug J, Pinto D, Vincent J, Zwaigenbaum L, Fernandez B, Roberts W, Szatmari P, Scherer SW: Contribution of SHANK3 mutations to autism spectrum disorder. Am J Hum Genet 2007, 81(6):1289-1297.

11. Gauthier J, Champagne N, Lafrenière RG, Xiong L, Spiegelman D, Brustein $E$, Lapointe M, Peng H, Côté M, Noreau A, Hamdan FF, Addington AM, Rapoport JL, Delisi LE, Krebs MO, Joober R, Fathalli F, Mouaffak F, Haghighi AP, Néri C, Dubé MP, Samuels ME, Marineau C, Stone EA, Awadalla P, Barker PA, Carbonetto S, Drapeau P, Rouleau GA: De novo mutations in the gene encoding the synaptic scaffolding protein SHANK3 in patients ascertained for schizophrenia. Proc Natl Acad Sci USA 2010, 107(17):7863-7868.

12. Gong Y, Lippa CF, Zhu J, Lin Q, Rosso AL: Disruption of glutamate receptors at Shank-postsynaptic platform in Alzheimer's disease. Brain research 2009, 1292:191-198. 
13. Roselli F, Hutzler P, Wegerich Y, Livrea P, Almeida OF: Disassembly of shank and homer synaptic clusters is driven by soluble beta-amyloid(140) through divergent NMDAR-dependent signalling pathways. PLoS one 2009, 4(6):6011.

14. Roselli F, Tirard M, Lu J, Hutzler P, Lamberti P, Livrea P, Morabito M, Almeida OF: Soluble beta-amyloid1-40 induces NMDA-dependent degradation of postsynaptic density-95 at glutamatergic synapses. J Neurosci 2005, 25(48):11061-11070.

15. Roselli F, Livrea P, Almeida OF: CDK5 is essential for soluble amyloid $\beta$ induced degradation of GKAP and remodeling of the synaptic actin cytoskeleton. PLOS one 2011, 6(7):23097.

16. Baron MK, Boeckers TM, Vaida B, Faham S, Gingery M, Sawaya MR, Salyer D, Gundelfinger ED, Bowie JU: An architectural framework that may lie at the core of the postsynaptic density. Science 2006, 311(5760):531-535.

17. Grabrucker AM, Knight MJ, Proepper C, Bockmann J, Joubert M, Rowan M, Nienhaus GU, Garner CC, Bowie JU, Kreutz MR, Gundelfinger ED, Boeckers TM: Concerted action of zinc and ProSAP/Shank in synaptogenesis and synapse maturation. EMBO J 2011, 30(3):569-581.

18. Gundelfinger ED, Boeckers TM, Baron MK, Bowie JU: A role for zinc in postsynaptic density asSAMbly and plasticity? Trends Biochem Sci 2006, 31(7):366-373

19. Frederickson CJ, Bush Al: Synaptically released zinc: physiological functions and pathological effects. Biometals 2001, 14(3-4):353-366.

20. Lee JY, Mook-Jung I, Koh JY: Histochemically reactive zinc in plaques of the Swedish mutant beta-amyloid precursor protein transgenic mice. $J$ Neurosci 1999, 19(11):RC10.

21. Lovell MA, Robertson JD, Teesdale WJ, Campbell JL, Markesbery WR Copper, iron and zinc in Alzheimer's disease senile plaques. J Neurol Sci 1998, 158(1):47-52.

22. Suh SW, Jensen KB, Jensen MS, Silva DS, Kesslak PJ, Danscher G, Frederickson CJ: Histochemically-reactive zinc in amyloid plaques, angiopathy, and degenerating neurons of Alzheimer's diseased brains. Brain Res 2000, 852(2):274-278.

23. Atwood CS, Scarpa RC, Huang X, Moir RD, Jones WD, Fairlie DP, Tanzi RE, Bush Al: Characterization of copper interactions with alzheimer amyloid beta peptides: identification of an attomolar-affinity copper binding site on amyloid beta1-42. J Neurochem 2000, 75(3):1219-1233.

24. Bush Al, Pettingell WH, Multhaup $G$, d. Paradis $M$, Vonsattel JP, Gusella JF, Beyreuther K, Masters CL, Tanzi RE: Rapid induction of Alzheimer Abeta amyloid formation by zinc. Science 1994, 265(5177):1464-1467.

25. Miller $Y$, Ma B, Nussinov R: Zinc ions promote Alzheimer Abeta aggregation via population shift of polymorphic states. Proc Natl Acad SCi USA 2010, 107(21):9490-9495.

26. Boeckers TM, Kreutz MR, Winter C, Zuschratter W, Smalla KH, Sanmarti-Vila L, Wex H, Langnaese K, Bockmann J, Garner CC, Gundelfinger ED: Proline-rich synapse-associated protein-1/cortactin binding protein 1 (ProSAP1/ CortBP1) is a PDZ-domain protein highly enriched in the postsynaptic density. J Neurosci 1999, 19(15):6506-6518.

27. Sala C, Piëch V, Wilson NR, Passafaro M, Liu G, Sheng M: Regulation of dendritic spine morphology and synaptic function by Shank and Homer. Neuron 2001, 31(1):115-130.

28. Coyle P, Zalewski PD, Philcox JC, Forbes IJ, Ward AD, Lincoln SF, Mahadevan I, Rofe AM: Measurement of zinc in hepatocytes by using a fluorescent probe, zinquin: relationship to metallothionein and intracellular zinc. Biochem J 1994, 303(3):781-786.

29. Yang DS, McLaurin J, Qin K, Westaway D, Fraser PE: Examining the zinc binding site of the amyloid-beta peptide. Eur J Biochem 2000, 267(22):6692-6698

30. Talmard C, Bouzan A, Faller P: Zinc binding to amyloid-beta: isothermal titration calorimetry and $\mathrm{Zn}$ competition experiments with $\mathrm{Zn}$ sensors. Biochemistry 2007, 46(47):13658-13666.

31. Danielsson J, Pierattelli R, Banci L, Gräslund A: High-resolution NMR studies of the zinc-binding site of the Alzheimer's amyloid beta-peptide. FEBS 2007, 274(1):46-59.

32. Lacor PN, Buniel MC, Furlow PW, Clemente AS, Velasco PT, Wood M, Viola KL, Klein WL: Abeta oligomer-induced aberrations in synapse composition, shape, and density provide a molecular basis for loss of connectivity in Alzheimer's disease. J Neurosci 2007, 27:796-807.

33. Kodali $R$, Williams AD, Chemuru $S$, Wetzel R: Abeta(1-40) forms five distinct amyloid structures whose beta-sheet contents and fibril stabilities are correlated. J Mol Biol 2010, 401(3):503-517.
34. Selkoe DJ: Soluble oligomers of the amyloid beta-protein impair synaptic plasticity and behavior. Behav Brain Res 2008, 192:106-113.

35. Lambert MP, Barlow AK, Chromy BA, Edwards C, Freed R, Liosatos M, Morgan TE, Rozovsky I, Trommer B, Viola KL, Wals P, Zhang C, Finch CE, Krafft GA, Klein WL: Diffusible, nonfibrillar ligands derived from Abeta1-42 are potent central nervous system neurotoxins. Proc Natl Acad Sci USA 1998, 95:6448-6453.

36. Klein WL, Krafft GA, Finch CE: Targeting small Abeta oligomers: the solution to an Alzheimer's disease conundrum? Trends Neurosci 2001, 24:219-224.

37. Walsh DM, Selkoe DJ: Oligomers on the brain: the emerging role of soluble protein aggregates in neurodegeneration. Protein Pept Lett 2004 11:213-228.

38. Klyubin I, Betts V, Welzel AT, Blennow K, Zetterberg $H$, Wallin A, Lemere CA, Cullen WK, Peng Y, Wisniewski T, Selkoe DJ, Anwyl R, Walsh DM, Rowan MJ: Amyloid beta protein dimer-containing human CSF disrupts synaptic plasticity: prevention by systemic passive immunization. J Neurosci 2008, 28:4231-4237.

39. Bush Al, Pettingell WH, Paradis MD, Tanzi RE: Modulation of Abeta adhesiveness and secretase site cleavage by zinc. J Biol Chem 1994, 269(16):12152-12158

40. Matsubara T, Hiura Y, Kawahito O, Yasuzawa M, Kawashiro K: Selection of novel structural zinc sites from a random peptide library. FEBS Lett 2003, 555(2):317-321.

41. Adlard PA, Parncutt JM, Finkelstein DI, Bush Al: Cognitive loss in zinc transporter-3 knock-out mice: a phenocopy for the synaptic and memory deficits of Alzheimer's disease? J Neurosci 2010, 30(5):1631-1636.

42. Cole TB, Wenzel HJ, Kafer KE, Schwartzkroin PA, Palmiter RD: Elimination of zinc from synaptic vesicles in the intact mouse brain by disruption of the ZnT3 gene. Proc Natl Acad Sci USA 1999, 96(4):1716-1721.

43. Deshpande A, Kawai H, Metherate R, Glabe CG, Busciglio J: A Role for Synaptic Zinc in Activity-Dependent $A \beta$ Oligomer Formation and Accumulation at Excitatory Synapses. J Neurosci 2009, 29(13):4004-4015.

44. Gylys KH, Fein JA, Yang F, Wiley DJ, Miller CA, Cole GM: Synaptic changes in Alzheimer's disease: increased amyloid-beta and gliosis in surviving terminals is accompanied by decreased PSD-95 fluorescence. Am J Pathol 2004, 165:1809-1817

45. Koffie RM, Meyer-Luehmann M, Hashimoto T, Adams KW, Mielke ML, GarciaAlloza M, Micheva KD, Smith SJ, Kim ML, Lee VM, Hyman BT, SpiresJones TL: Oligomeric amyloid beta associates with postsynaptic densities and correlates with excitatory synapse loss near senile plaques. Proc Natl Acad Sci USA 2009, 106:4012-4017.

46. Sze Cl, Troncoso JC, Kawas C, Mouton P, Price DL, Martin L: Loss of the presynaptic vesicle protein synaptophysin in hippocampus correlates with cognitive decline in Alzheimer disease. J Neuropathol Exp Neurol 1997, 56(8):933-944.

47. Zhan SS, Beyreuther K, Schmitt HP: Quantitative assessment of the synaptophysin immuno-reactivity of the cortical neuropil in various neurodegenerative disorders with dementia. Dementia 1993, 4(2):66-74.

48. Viola KL, Velasco PT, Klein WL: Why Alzheimer's is a disease of memory: the attack on synapses by A beta oligomers (ADDLs). J Nutr Health Aging 2008, 12:51-57.

49. Kandimalla KK, Scott OG, Fulzele S, Davidson MW, Poduslo JF: Mechanism of neuronal versus endothelial cell uptake of Alzheimer's disease amyloid beta protein. PLoS One 2009, 4(2):e4627.

50. Lai AY, McLaurin J: Mechanisms of amyloid-Beta Peptide uptake by neurons: the role of lipid rafts and lipid raft-associated proteins. Int $J$ Alzheimers Dis 2010, 2011:548380.

51. LaFerla FM, Green KN, Oddo S: Intracellular amyloid-beta in Alzheimer's disease. Nat Rev Neurosci 2007, 8(7):499-509.

52. Mocchegiani E, Malavolta M: Zinc dyshomeostasis, ageing and neurodegeneration: implications of A2M and inflammatory gene polymorphisms. J Alzheimers Dis 2007, 12(1):101-109.

53. Carrasco J, Adlard P, Cotman C, Quintana A, Penkowa M, Xu F, Van Nostrand WE, Hidalgo J: Metallothionein-I and -III expression in animal models of Alzheimer disease. Neuroscience 2006, 143(4):911-922.

54. Lyubartseva G, Smith JL, Markesbery WR, Lovell MA: Alterations of zinc transporter proteins ZnT-1, ZnT-4 and ZnT-6 in preclinical Alzheimer's disease brain. Brain Pathol 2010, 20(2):343-350

55. Zheng $W$, Wang T, Yu D, Feng WY, Nie YX, Stoltenberg M, Danscher G, Wang ZY: Elevation of zinc transporter ZnT3 protein in the cerebellar 
cortex of the AbetaPP/PS1 transgenic mouse. J Alzheimers Dis 2010, 20(1):323-331.

56. Baum L, Chan IH, Cheung SK, Goggins WB, Mok V, Lam L, Leung V, Hui E, Ng C, Woo J, Chiu HF, Zee BC, Cheng W, Chan MH, Szeto S, Lui V, Tsoh J, Bush Al, Lam CW, Kwok T: Serum zinc is decreased in Alzheimer's disease and serum arsenic correlates positively with cognitive ability. Biometals 2010, 23(1):173-179.

57. Corona C, Masciopinto F, Silvestri E, Del Viscovo A, Lattanzio R, Sorda RL, Ciavardelli D, Goglia F, Piantelli M, Canzoniero LM, Sensi SL: Dietary zinc supplementation of 3xTg-AD mice increases BDNF levels and prevents cognitive deficits as well as mitochondrial dysfunction. Cell Death and Disease 2010, 1:1-8.

58. Greenough MA, Volitakis I, Li QX, Laughton K, Evin G, Ho M, Dalziel AH, Camakaris J, Bush Al: Presenilins promote the cellular uptake of copper and zinc and maintain $\mathrm{Cu}$-chaperone of sod1-dependent $\mathrm{Cu} / \mathrm{Zn}$ superoxide dismutase activity. J Biol Chem 2011.

59. Di Stefano A, Sozio P, Cerasa LS, lannitelli A, Cataldi A, Zara S, Giorgioni G, Nasuti C: Ibuprofen and lipoic acid diamide as co-drug with neuroprotective activity: pharmacological properties and effects in betaamyloid (1-40) infused Alzheimer's disease rat model. Int I Immunopathol Pharmacol 2010, 2:589-599.

60. Schmeisser MJ, Grabrucker AM, Bockmann J, Boeckers TM: Synaptic crosstalk betweeen $\mathrm{N}$-methyl-D-aspartate receptors and LAPSER1-betacatenin at excitatory synapses. J Biol Chem 2009, 284(42):29146-29157.

\section{doi:10.1186/1750-1326-6-65}

Cite this article as: Grabrucker et al: Amyloid beta protein-induced zinc sequestration leads to synaptic loss via dysregulation of the ProSAP2/ Shank3 scaffold. Molecular Neurodegeneration 2011 6:65.

\section{Submit your next manuscript to BioMed Central and take full advantage of:}

- Convenient online submission

- Thorough peer review

- No space constraints or color figure charges

- Immediate publication on acceptance

- Inclusion in PubMed, CAS, Scopus and Google Scholar

- Research which is freely available for redistribution

Submit your manuscript at www.biomedcentral.com/submit 